\title{
Unravelling calcrete environmental controls in volcanic islands, Gran Canaria Island, Spain
}

\author{
Ana María Alonso-Zarza ${ }^{\mathrm{a}, *}$, Álvaro Rodríguez-Berriguete ${ }^{\mathrm{a}}$, Andrea Martín-Pérez ${ }^{\mathrm{b}}$, \\ Rebeca Martín-García ${ }^{a}$, Inmaculada Menéndez ${ }^{c}$, José Mangas ${ }^{c}$ \\ ${ }^{a}$ Departamento de Mineralogía y Petrología, Fac. CC. Geológicas, Instituto de Geociencias, CSIC. Universidad Complutense, C/ José Antonio Novais, 12 , 28040 Madrid, \\ Spain \\ ${ }^{\mathrm{b}}$ Institute of Palaeontology Research Centre of the Slovenian Academy of Sciences and Arts, Novi trg 2, 1000 Ljubljana, Slovenia \\ ${ }^{\mathrm{c}}$ Instituto de Oceanografía y Cambio Global, IOCAG, Facultad de Ciencias del Mar, Universidad de Las Palmas de Gran Canaria, 35017 Las Palmas de Gran Canaria, \\ Spain
}

\section{A R T I C L E I N F O}

\section{Keywords:}

Pedogenic

Aeolian dust

Isotopes

Ooids

Roots

Laminar horizons

\begin{abstract}
A B S T R A C T
Volcanic islands are unique contexts to analyze the controls on calcrete development in settings with varied relief, climate and vegetation, and lacking carbonate host rocks. This paper discusses the formation of Quaternary calcrete profiles in Gran Canaria volcanic Island, under direct influence of the SAL (Saharian Air Layer). Calcrete profiles are multi-storey and composed of prismatic, massive, laminar, pisolithic, ooid-bearing, sandy mudstones with rhizoliths and brecciated horizons. Host rocks include basalts, siliceous mudstones, volcanic sands and gravels and bioclastic-rich sands. Carbonate is mostly calcite but some dolomite occurs in massive horizons. The main microfabrics include laminated micrite, fine crystalline dolomite, desiccated micrite, micrite-clay groundmass, oriented Mg-rich clays, peloids, spherulites and coated grains. $\delta^{13} \mathrm{C}$ varies from -3.26 to $-9.18 \%$ VPDB and $\delta^{18} \mathrm{O}$ from +0.86 to $-3.24 \%$ VPDB. The ${ }^{87} \mathrm{Sr} /{ }^{86} \mathrm{Sr}$ ratios are between 0.707504 and 0.708860, indicating that calcium was mostly supplied from the $\mathrm{CaCO}_{3}$-rich aeolian dust coming from the Sahara Desert.

Calcrete profiles are mostly pedogenic with roots and microorganisms enabling carbonate precipitation within the soils. The correlation trend of $\delta^{13} \mathrm{C}$ and $\delta^{18} \mathrm{O}$ points to a climate control on precipitation, with the heavier isotope values in the horizons containing dolomite. Sedimentation rates interplayed with calcrete formation processes and erosion to outline the profiles/horizons. Amalgamated laminar horizons formed when the rate of calcrete formation was higher than sedimentation and erosion, whereas areas or periods with relatively higher sedimentation allowed the separation of calcrete horizons.

The direction of the winds supplying aeolian dust, and the varied relief, vegetation and climate favored better development of calcretes in the relatively arid and lowland areas of the eastern side of the island. Our study shows that calcretes contain the record of the paleoenvironmental controls that operated in volcanic islands with no previous carbonate substrates.
\end{abstract}

\section{Introduction}

Calcretes are unique archives of ancient landscapes, and their distribution and features are good indicators of the climate, vegetation and relief (Goudie, 1973; Esteban and Klappa, 1983; Alonso-Zarza, 2003; Tanner, 2010). Special interest has been devoted to alluvial/fluvial basins where calcretes are key elements to understand the fluvial regimes, the architecture of the deposits and the overall pedostratigraphy of the basins (Wright and Alonso-Zarza, 1990; Mack and James, 1993;
Wright and Marriott, 1996; Wright, 2007; Alonso-Zarza and Wright, 2010). In Quaternary deposits, calcretes show well the evolution of fluvial entrenchment through space and time (Meléndez et al., 2011). Less attention has been paid to calcretes/dolocretes developed in volcanic terrains, where the special characteristics of the host rock have allowed the formation of a varied suite of minerals, including dolomite, Mg-Ca-rich silicate minerals, such as different types of zeolites, smectites, or talc-like minerals (Capo et al., 2000; Whipkey and Hayob, 2008; Alonso-Zarza et al., 2016; Diaz-Hernandez et al., 2018). By

\footnotetext{
* Corresponding author.

E-mail addresses: alonsoza@ucm.es (A.M. Alonso-Zarza), arberriguete@geo.ucm.es (Á. Rodríguez-Berriguete), andrea.martin-perez@zrc-sazu.si (A. Martín-Pérez), rebequinya25@gmail.com (R. Martín-García), inma.menendez@gmail.com (I. Menéndez), jose.mangas@ulpgc.es (J. Mangas).
} 
analogy, volcanic islands can be considered as small continents in which the different relief, climate, vegetation, aeolian dust input or sedimentation and erosion processes prevailing along the different areas of the island interact to control the distribution and characteristic of calcretes/dolocretes. The Canary Islands situated in the vicinity of the Sahara Desert, under direct influence of the SAL (Saharan Air Layer) (Prospero and Lamb, 2003; Menéndez et al., 2007; Muhs et al., 2010), provide a unique setting for the understanding of the specific climatic/ vegetation needed to accumulate calcium carbonate in soil profiles, and to discuss the role of host rock mineralogy versus aeolian dust control in calcrete formation. Due to the important contamination by minerals from the host rock it is almost impossible to obtain good dating of these calcretes. If this were possible, and providing for the interference of calcrete formation with marine and/or aeolian deposition it would be possible to report good data on sea level changes. In spite of the lack of dating, the characteristics of the calcretes and their interlayering with sediments give relevant data on the dynamic of coastal areas and the possible involvement of marine groundwater in some profiles.

In this paper, we describe calcrete profiles developed along Gran Canaria Island. Some are multi-storey profiles reflecting complex sedimentation-erosion-pedogenesis relationships. Other are simpler and composed by laminar horizons and rhizoliths interlayered with the host rock. The aim of this work is to show that on volcanic islands the accumulation of calcium carbonate within the soils is controlled by the interplay between relief, climate, vegetation and calcium supply by aeolian dust.

\section{Background}

\subsection{Geological setting}

The Canary Islands constitute a Cenozoic intraplate volcanic archipelago developed on oceanic Jurassic lithosphere (Hollik et al., 1991; Schmincke et al., 1998; Steiner et al., 1998). Gran Canaria Island has a nearly circular shape of ca $45 \mathrm{~km}$ (Fig. 1) in diameter and a maximum altitude of $1949 \mathrm{~m}$ at its centre. It grew since the Miocene to present times in two volcanic stages, forming a variety of basaltic to phonolitic materials, which continued until the Holocene, interspersed with several inactive volcanic and erosive periods (Balcells et al., 1992; Pérez-Torrado et al., 1995; Carracedo et al., 2008). In addition to the volcanic rocks, alluvial deposits, beaches, eolianites, paleosols and spring carbonate deposits are common in the Island, commonly overlaying the volcanic material. Some paleosols are preserved between volcanic deposits, since the beginning of the basic subaerial shield eruptions $(14.5 \mathrm{Ma})$ towards the more recent volcanism $(<3.6 \mathrm{Ma})$. Some of these paleosols seem to reflect more warm-humid conditions than the present climate (Menéndez et al., 2019). Calcretes are commonly found in the eastern Canary Islands, were they formed during the less arid Pleistocene periods (Criado, 1988; Alonso-Zarza and Silva, 2002, Genise et al., 2013) due to the calcium sourced by the aeolian dust (Huerta et al., 2015). Although in Fuerteventura and Lanzarote islands most of the calcretes are dominated by calcite, Cuadros et al. (2016) and Diaz-Hernandez et al. (2018) described the presence of dolomite and Mg-rich clays in calcretes from Gran Canaria Island.

Climate in Gran Canaria, controlled mainly by trade winds and the high relief of the centre of the island, brings more humidity to the northern flank than in the southern one. Mean annual temperatures are about $20^{\circ} \mathrm{C}$. Torrential rainfalls exceeding $800 \mathrm{~mm}$ /year occur mainly in winter, mostly at the high altitudes of the northern flank of the island (Jaén and Suárez, 2012; Mestre and Felipe, 2012). The Saharan plume dust affects the Canary Islands about $30 \%$ of the year. These dust episodes are known locally as "calima" and usually last 3-5 days (http:// www.calima.ws/). The northern branch of the high-altitude SAL transports the dust to latitudes north of the Canary Islands mostly during the summer (Prospero and Lamb, 2003). During these events, dust is transported towards the Canary Islands, generally at low altitudes $(<2000 \mathrm{~m}$ ) (Menéndez et al., 2009a, Fig. 2). The main direction of dust transport in the SAL is to the west at latitudes between $15^{\circ}$ and $21^{\circ} \mathrm{N}$ (south of the Canary Islands). A south-to-north component of flow can occur in the lee of an easterly wave (Pye, 1987; Muhs et al., 2010). Part of the dust carried by the SAL sinks into the lower atmosphere and it is transported to the islands by northeast trade winds (Bozzano et al., 2002; von Suchodoletz et al., 2009; von Suchodoletz et al., 2010). Currently, deposition rate of Saharan dust in this region is about $15.6 \mathrm{~g} /$ $\mathrm{m}^{2}$ year (Prospero, 1996; Goudie and Middleton, 2001). There is an inverse relationship of gravitational settling with respect to altitude (Menéndez et al., 2007). The mean grain size distribution of dust particles is $15 \mu \mathrm{m}$ (Menéndez et al., 2009b).

The distribution of potential natural vegetation along Gran Canaria Island follows a concentrical trend, responding to climate and relief, with some modification due to the prevailing rocks (Del-Arco et al., 2002). Of special interest is the presence of halophilous and xerofilous species such as Chenoloides tomentosa, Suaeda mollis, Launaea arborescens and Schizogyne sericea in eastern such as Gando or Arinaga areas.
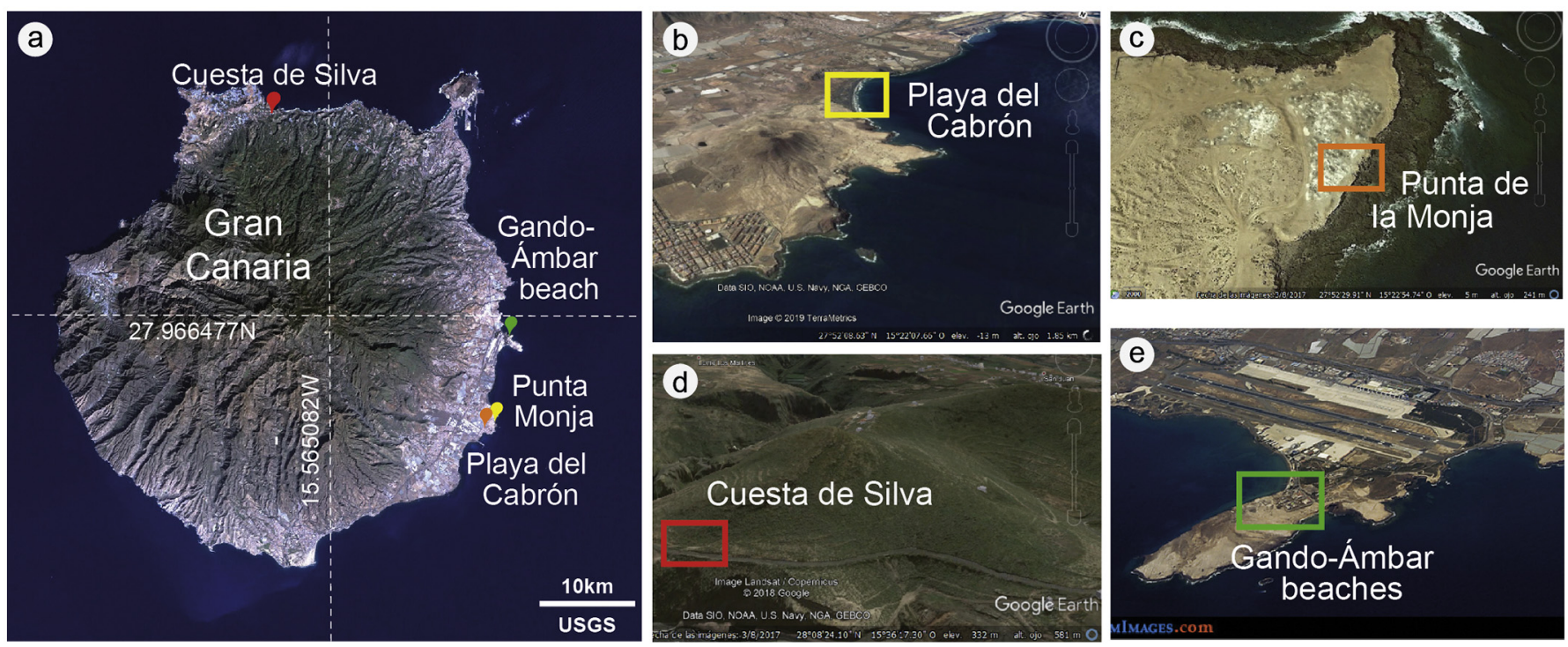

Fig. 1. A) General geographic situation of Gran Canaria Island and the studied profiles. B) Playa del Cabrón. C) Punta de la Monja. D) Cuesta de Silva. E) Gando and Ámbar. 

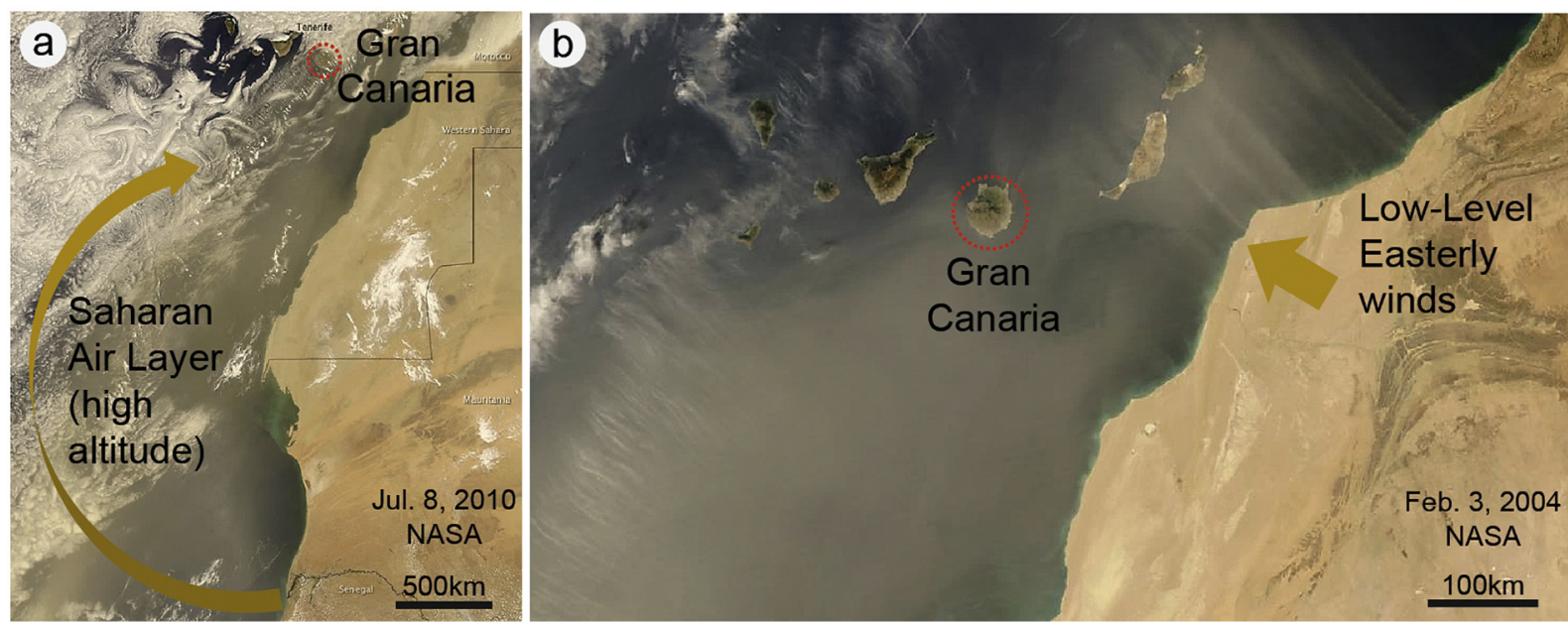

Fig. 2. A) General distribution of the SAL to the west of the Sahara Desert. B) Location of Gran Canaria Island in relation with SAL.

In the northern Cuesta de Silva area the dominant plant association is Euphorbietum balsamiferae, typical of arid and semiarid areas of Canary Islands (del Arco et al., 2003).

\section{Material and methods}

Five representative calcrete profiles were described in the field and 52 samples were collected. Thin sections were studied by transmission light microscopy. Due to fragility the samples were embedded in EPOXY resin in a vacuum system. The thin sections were stained with red alizarin to differentiate calcite and dolomite.

The Saharan dust samples were collected in 2003, at Gando (10 m above sea level) and Tafira (280 $\mathrm{m}$ a.s.l.) sites, as passive deposition on glass trays (Pirex), with an internal area of $0.097 \mathrm{~m}^{2}$. The trays were placed on a building roof. The sampling procedure consisted of rinsing the glass trays with deionized water and scraping material adhered to the glass substrate with a rubber spatula, collecting the rinsing water in glass bottles, which were subsequently oven-dried below $50{ }^{\circ} \mathrm{C}$ before weighed on an analytical balance, model CRISTAL200 of $0.1 \mathrm{mg}$ of precision.

The $\delta^{13} \mathrm{C}$ and $\delta^{18} \mathrm{O}$ values for dolomite and calcite samples were determined at the Scientific and Technical Services of the Barcelona University (Spain). These analyses were carried out on powdered samples. To analyze calcite and dolomite, the samples were attacked with hydrochloric acid diluted to $10 \%$, measuring the isotopic ratios for calcite after one-minute attack. Twenty minutes later, the samples were washed with distilled water, filtered and oven dried, and values for dolomite were determined. $\mathrm{CO}_{2}$ was extracted using a Thermo Finnigan Carbonate Kiel Device III isotopic analyzer, with a Thermo Finnigan MAT-252 spectrometer, according to the McCrea (1950) method. Values obtained were corrected using the NBS-19 and NBS-18 standard for $\delta^{13} \mathrm{C}$ and the standard NBS-19 for $\delta^{18} \mathrm{O}$. Results are expressed in partsper thousand (\%) referred to VPDB standard. Reproducibility obtained was better than $0.03 \%$.

${ }^{87} \mathrm{Sr} /{ }^{86} \mathrm{Sr}$ isotope ratios were measured at the Geochronology and Isotope Geochemistry facility of the Universidad Complutense de Madrid using a VG TIMS mass spectrometer. Samples were dissolved in $2.5 \mathrm{~N} \mathrm{HCl}$, centrifuged and then evaporated. Residue was again dissolved in $2.5 \mathrm{~N} \mathrm{HCl}$. The analytical precision for ${ }^{87} \mathrm{Sr} /{ }^{86} \mathrm{Sr}$ values is \pm 0.000015 (referred to standard NBS-987).

\section{Results}

\subsection{Calcrete profiles}

The studied profiles are (Fig. 1): Playa del Cabrón $\left(27^{\circ} 51^{\prime} 14^{\prime \prime} \mathrm{N}\right.$, $\left.15^{\circ} 23^{\prime} 12^{\prime \prime} \mathrm{W}\right)$, Punta de la Monja $\left(27^{\circ} 52^{\prime} 26^{\prime \prime} \mathrm{N}, 15^{\circ} 22^{\prime} 55^{\prime \prime} \mathrm{W}\right)$, Gando ( $\left.27^{\circ} 56^{\prime} 02^{\prime \prime} \mathrm{N}, 15^{\circ} 22^{\prime} 14^{\prime \prime} \mathrm{W}\right)$, Playa del Ámbar ( $\left.27^{\circ} 56^{\prime} 21^{\prime \prime} \mathrm{N}, 15^{\circ} 22^{\prime} 07^{\prime \prime} \mathrm{W}\right)$ and Cuesta de Silva $\left(28^{\circ} 08^{\prime} 32^{\prime \prime} \mathrm{N}, 15^{\circ} 36^{\prime} 16^{\prime \prime} \mathrm{W}\right)$. The five profiles are formed by well differentiated carbonate horizons, whose arrangement is varied and does not correspond to the classic horizon arrangement commonly described in calcretes (Gile et al., 1966; Esteban and Klappa, 1983; Machette, 1985; Alonso-Zarza et al., 1998). Each of the profiles has specific characteristics depending on the type and arrangement of the horizons and their micromorphology (Fig. 3). Four of the profiles are located in different littoral areas of the east of the Island, whereas Cuesta de Silva profile is situated in the north of the Island at an altitude of $240 \mathrm{~m}$.

The host rock (substrate) of the profiles includes lava flows, gravels, sands and mudstones. Gravels and sands are composed of volcanic fragments, but sands also include bioclasts (red algae, mollusks, forams). In cases, the carbonate content of some beach sands can reach 50\% (Casamayor et al., 2019; Burgoa-Torrontegui et al., 2019). Mudstones are siliceous, composed by illite, smectite and volcanic grains. Along the same calcrete profile the host sediment may vary vertically and laterally. Most of the lava flows that constitute the host rock of some of the profiles belong to the Post-Roque Nublo Group and in the study area they are basanites and foidites with high amounts of $\mathrm{MgO}$, $\mathrm{FeO}, \mathrm{CaO}$ and $\mathrm{TiO}_{2}$ and low abundance of $\mathrm{SiO}_{2}, \mathrm{Al}_{2} \mathrm{O}_{3}, \mathrm{Na}_{2} \mathrm{O}, \mathrm{K}_{2} \mathrm{O}$ and $\mathrm{P}_{2} \mathrm{O}_{5}$, which are characteristic of alkaline ultramaphic rocks (Balcells and Barrera, 1990; Mangas et al., 2018). The lava flows are younger than $3.9 \pm 0.25 \mathrm{Ma}$ in age (Mangas et al., 2018).

Insect traces (Rebuffoichnus Guanche, Genise et al., 2013) are common in all the profiles. The carbonate is mostly calcite. In Gando, Cuesta de Silva, Ámbar and Monjas profiles calcite is dominant with minor amount of dolomite, whereas in Cabrón profile dolomite is dominant.

The Playa del Cabrón profile, $3 \mathrm{~m}$ thick, developed on basalts and gravels with basalt clasts, but interbedded sandy mudstones are common as well as lapilli beds at the top (Fig. 4A). The mudstones are composed of illite, smectites and etched volcanic grains and bioclasts. This profile is mostly composed of dolomite. Main horizons include mudstones with rhizoliths, prismatic and wavy laminar horizons. Large basalt clasts occur all along the profile.

The Punta de la Monja profile is a thick $(8 \mathrm{~m})$ multistorey profile. The lower part is composed of red irregular carbonate laminae of $\mathrm{dm}$ thickness. Large (cm to $\mathrm{dm}$ ) volcanic clasts are common as well as pisoliths having volcanic fragments, sands or previous carbonate laminae as nuclei. Some of the dm-thick laminae are broken and coated by laminated carbonate. The intermediate part is composed by an alternation of carbonates with wavy, pseudo-anticline structure (Price, 1925; Watts, 1977) (Fig. 4B) and coarse sands with large volcanic fragments, 


\section{Punta de la Monja}

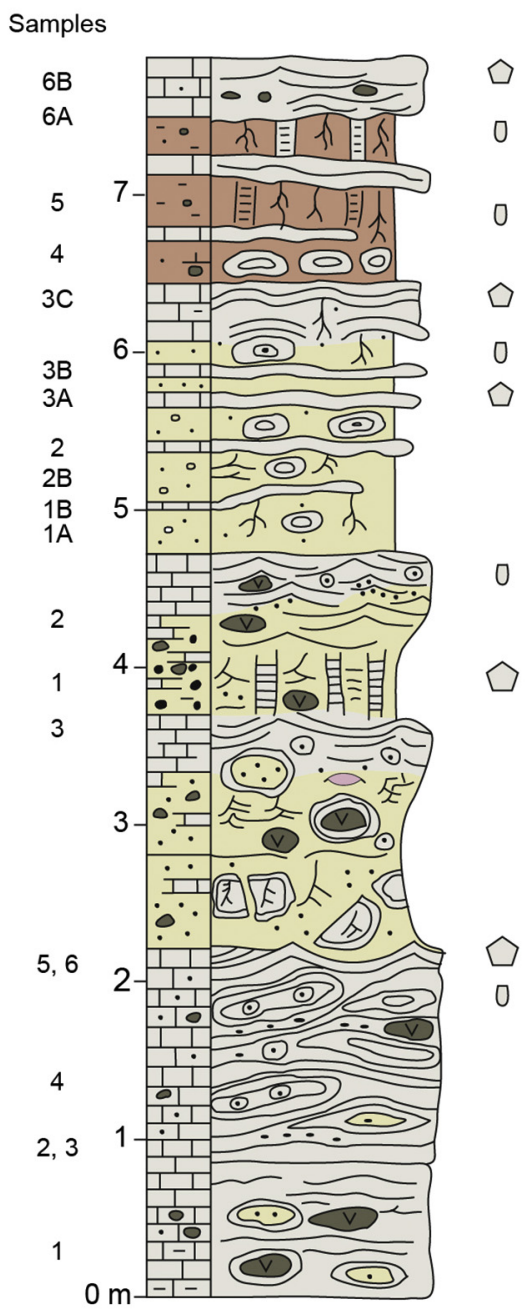

\begin{tabular}{|c|c|}
\hline ए & Limestones \\
\hline & Mudstones \\
\hline & Gravels \\
\hline & Sands \\
\hline- & Basalts \\
\hline & Lapilli \\
\hline
\end{tabular}
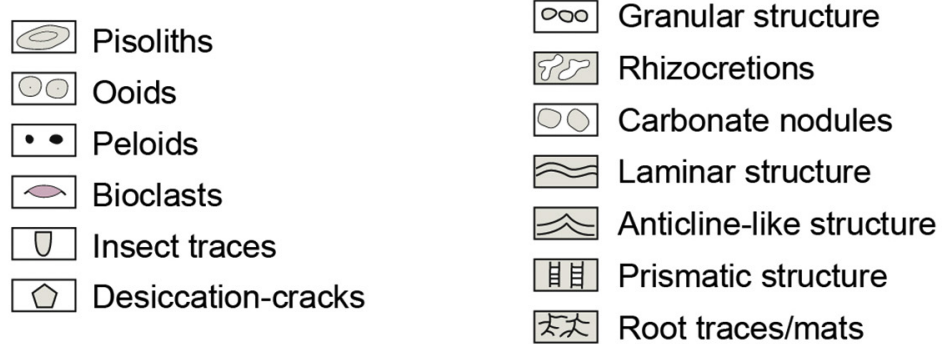

Fig. 3. Sedimentary logs of the five studied calcrete profiles.
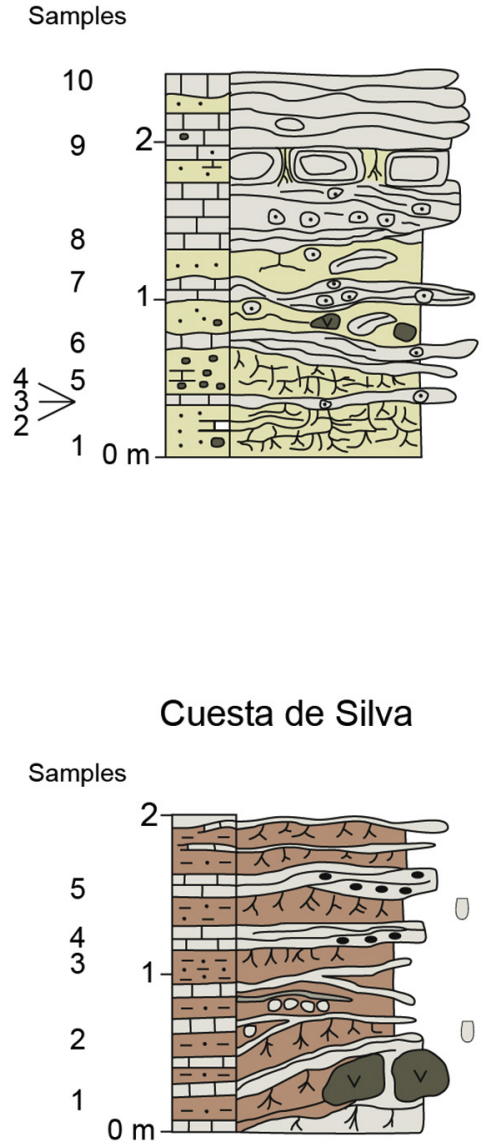

bioclasts (mollusks, red algae, equinoids, forams), ooids, reworked large pisoliths and root and insect traces. Carbonate prisms with horizontal desiccation cracks occur below the laminar horizons that constitute the top of the profile. Large ( $\mathrm{dm}$ in diameter) pisoliths are also common (Fig. 4C). The carbonate is mostly calcite but in a few cases, dolomite can reach $55 \%$.

The Cuesta de Silva profile is about $2 \mathrm{~m}$ thick, and relatively poorly developed, it consists of red sandy mudstones with root and insect traces (Rebuffoichnus Guanche, Genise et al., 2013) with interbedded horizontal laminar horizons, which connect vertically to form in cases an irregular "grilled-like" network (Fig. 4D). Calcified root-mats constitute most of the laminar horizons, although some of the carbonate laminae consist mostly of peloids. The carbonate is calcite but some samples contain up to $10 \%$ of dolomite.

The Ámbar profile, $3 \mathrm{~m}$ thick, develops on green sands and gravels both with volcanic clasts. Large pisoliths are common all along the profile (Fig. 4E). Well-developed prismatic structures with desiccation cracks constitute a characteristic but very irregular horizon (Fig. 4F). Bioclastic sands with fragments of pisoliths and rhizoliths compose the top of the profile.

The Gando profile, $2.5 \mathrm{~m}$ thick, developed on sands and sandy mudstones with both bioclastic and volcanic grains. The base shows 

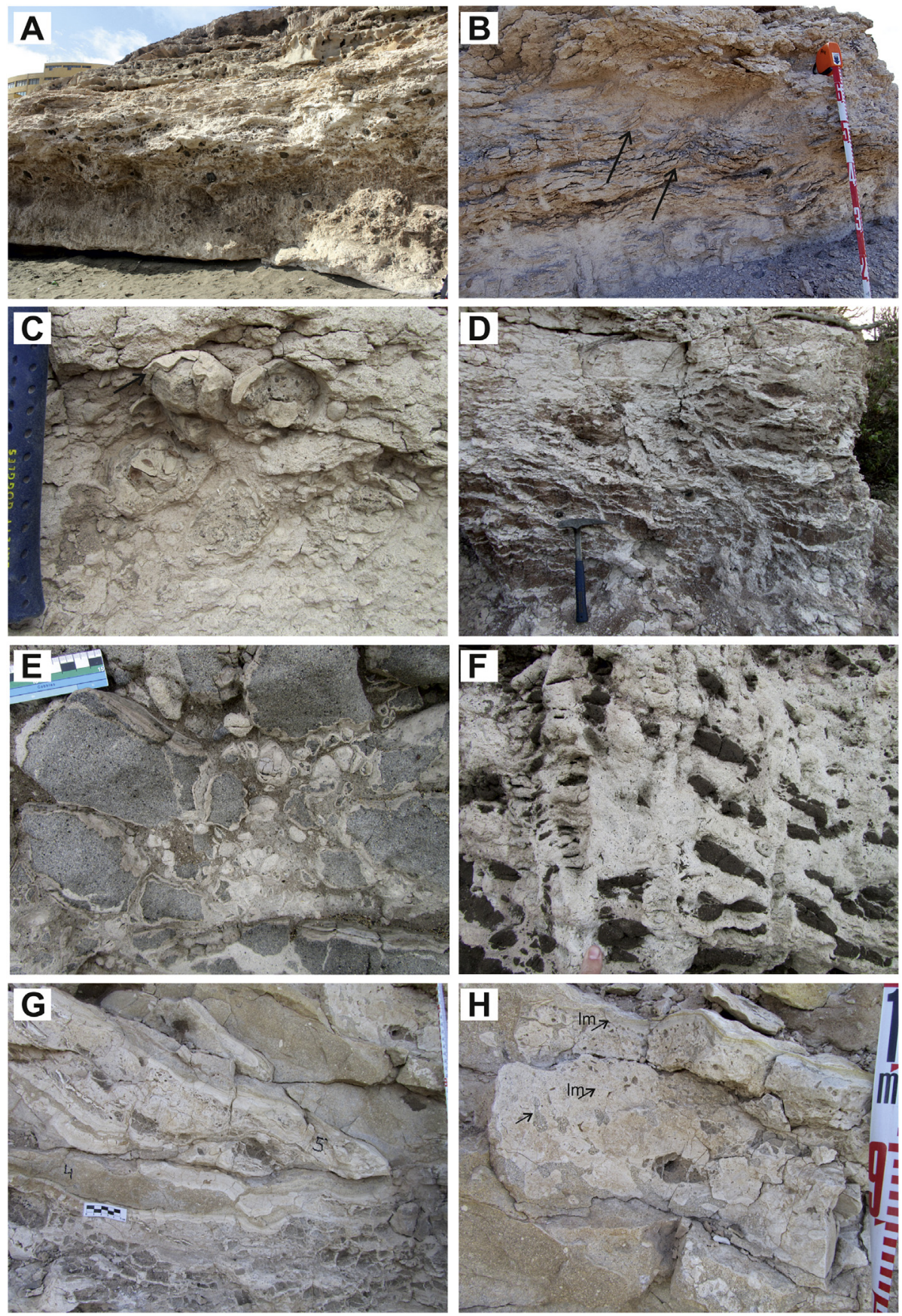

Fig. 4. A) Playa del Cabrón profile showing a lower prismatic horizon with coarse volcanic fragments overlain by a thick wavy laminar profile. B) Intermediate part of Monja profile showing a laminar wavy horizon with pseudo-anticline structures (arrowed) overlaying a prismatic horizon. C) Large pisoliths in Punta de la Monja profile. Their nuclei are coarse hybrid sands (volcanoclastic and bioclastic) and are coated by laminated micrite (arrowed). D) Laminar horizons in Cuesta de Silva profile are interlayered with brown mudstones in the base, but amalgamated at the top. Vertical connections between the horizontal laminae are seen. E) The base of Ámbar profile consists of large pisoliths with thin laminar coatings. The nuclei are composed of "in situ" brecciated green volcanoclastic sands. F) Prismatic horizon in Ámbar profile. The carbonate prisms with horizontal cracks replace dark volcanoclastic sands. The prisms together with the oblique irregular laminae give a general grilled structure. G) Gando profile is composed by an irregular interlayering of sandy mudstones with rhizoliths, laminar and ooid-bearing horizons. H) Close up view of Gando profile showing the irregular succession of ooid-bearing horizons with irregular vugs (arrowed), laminated micrite (lm, arrowed) and sands with ooids (base). The $\mathrm{cm}$ vugs are filled by sands with ooids. (For interpretation of the references to colour in this figure legend, the reader is referred to the web version of this article.) different horizons with the carbonate showing grilled-like structure within sands and sandy mudstones containing carbonate strings and rhizoliths (Fig. 4G). Irregular beds of ooids coated by thinly laminated carbonate compose most of the profile (Fig. $4 \mathrm{H}$ ). Reworking is shown by individualized fragments of ooids and laminar carbonate, partially coated by laminar carbonate. In the upper $2 \mathrm{~m}$ of the profile the layers show some inclination. The contact with more planar layers of the top of the profile is very irregular.

\subsection{Calcrete horizons}

The five studied profiles are composed by the following calcrete horizons (Fig. 3).

Prismatic horizons consist of vertical carbonate structures (prisms or cylinders) of about $5-10 \mathrm{~cm}$ across and from 0.1 to $1 \mathrm{~m}$ in length. They appear mostly in sandy mudstones substrates. The horizons are very irregular and within the same horizon thickness changes from a few decimeters to $1 \mathrm{~m}$. The bases and top of the horizons are irregular and gradual. The prisms are either of calcite or of dolomite. Commonly they show mm-wide horizontal desiccation cracks and some relics of the substrate. Some prisms are connected horizontally by thin $(\mathrm{mm})$ carbonate veins. The prims are made of dense micrite with desiccation cracks (horizontal and circumgranular) and in cases isolated irregular micrite fragments.

Massive horizons developed on sandy mudstones and are pale to dark brown, either soft or hard. The thickness varies between 10 and $50 \mathrm{~cm}$. The sand grains and the clays are embedded in carbonate. The sands consist of volcanic fragments and bioclasts, in cases gravel-sized. They have $\mathrm{cm}$ root traces with some branching and forming carbonate irregular nodules. In other cases, these massive horizons include large (dm) fragments of calcretes reworked from the underlying horizons.

Laminar horizons vary in thickness between few $\mathrm{cm}$ to about $1 \mathrm{~m}$. 
1). The thicker scale laminar horizons consist of dm layers of micrite with sands grains and rhizoliths. The layers are commonly irregular and show a wavy arrangement. Within the layers pisoliths, ooids, peloids and laminar crusts are common. 2) Intermediate thick laminar horizons are up to $10 \mathrm{~cm}$ layers with pseudo-anticlines, commonly broken at the top (Fig. 4B). They occur either amalgamated or interbedded with the host rock or other horizons and at the top of the profiles it is possible to observe a geometric network of cracks outlining the upper angle of the pseudo-anticlines. Calcified roots are common. 3) Laminar crusts consist of thinly laminated micrite (less than $1 \mathrm{~mm}$ ) (Fig. 4H). They are common at the top of any horizon but especially at the top of the thicker laminar horizons and coating any crack and/or discontinuities within any horizon.

Pisolithic horizons are very randomly distributed along the profiles, from 10 to $60 \mathrm{~cm}$ thick, and commonly discontinuous. The best developed occur in Ámbar and Monja profiles where $\mathrm{cm}$ to $\mathrm{dm}$ pisoliths appear within sandy substrates, either at the base or top of the profiles (Fig. 4C, E).

Ooid-bearing horizons occur in most of the profiles, but are prominent in Gando profile, where ooids form very continuous, but irregular layers. The layers are about $0.4 \mathrm{~m}$ thick and show no lamination. Insect traces are common as well as large reworked calcrete fragments from different types of horizons (massive, pisoliths and laminar crusts) (Figs. 3, 4G, H). Transitions with other horizons are sharp and irregular and ooids also infills cavities within underlying horizons.

Siliciclastic sandy mudstones with rhizoliths occur in the base of the profiles and interbedded with many of the other horizons, commonly constitute the base of many laminar horizons. The mudstones are composed by a clay matrix with etched sand grains, such as bioclasts, volcanic grains and calcrete fragments. The mudstones show grey to green mottling and thin laminar crusts connected by mostly vertical rhizoliths, giving in cases a grilled appearance to the horizons as in Gando profile. Insect traces are very common. Thickness varies from about $0.3 \mathrm{~m}$ in Gando to $\mathrm{m}$-scale in Cuesta de Silva (Figs. 3, 4G).

Brecciated horizons are irregularly distributed and mostly consist of any previous horizon that has been broken and is visible as large fragments included in any other horizon. They are well visible in Gando profile where laminar horizons are broken and the porosity is filled by ooids. Other types of brecciation are seen in Monja and Gando profile, were large broken fragments are coated by laminar crusts (Fig. 4E).

\subsection{Petrology of the calcretes}

The described horizons are composed by a variety of features observed in thin sections and electronic microscope, which are described below.

1. Laminated micrite is characteristic of the top of the profiles, as thin crusts and in the coating of the pisoliths (Fig. 5A). It consists of a variety of microfabrics including: laminated homogenous micrite with clastic grains (Fig. 5B), fine laminae with ooids (Fig. 5C), micrite laminae with some clays, micrite with alveolar septal structures and micrite with spherulites.

2. Desiccated micrite shows an irregular network of cracks that individualize angular and/or rounded micrite fragments. It contains peloids, etched grains, some surficially coated grains (Fig. 5D) and irregular micritic filaments. It may constitute the soil matrix of some horizons and the nucleus of the ooids and pisoids.

3. Fine crystalline dolomite (dolomicrite and dolomicrospar) occurs only in the Playa del Cabrón profile. It is very porous and contains peloids and irregular filaments of micrite about $0.2 \mathrm{~mm}$ across and $0.5 \mathrm{~mm}$ in length. Dolomicrite grains (angular or rounded), occasionally coated with micrite and/or clays are common. The filaments are either sparse or around moldic pores of rounded grains. The overall texture is very similar to desiccated micrite, but made of dolomite and slightly coarser crystalline (Fig. 5E). Under SEM the dolomite consists of rhombs of about $2-10 \mu \mathrm{m}$ across, some coarser rhombs appear filling the porosity (cements) or sparsely distributed (Fig. 5F). Locally some spheroidal dolomite coats some volcanic fragments and their internal vacuolar porosity.

4. Micrite-clay groundmass is constituted by a mix of micrite-clays and detrital grains forming relatively homogeneous masses with desiccation cracks in which irregular mm spheroidal fragments are individualized (Fig. 6A). Clay and micrite coatings are common on some of the grains. Fibrous carbonate cements appear on the micritic coatings and filaments.

5. Oriented clays and clay minerals occur sparsely in many of the studied samples mostly forming thin coatings on grains (Fig. 6B), and interlayered with the laminated micrite. They are brown in colour and due to their minor amount, it is not possible to assess their mineralogy. The orientation of the clays in grains coatings and in the groundmass follow two main perpendicular directions. In Cuesta de Silva samples, SEM images show that the clay coatings form very open arrangements and their spiky morphology and semiquantitative composition suggest they are Mg-rich clays (Fig. 6C and D).

6. Coated grains. The size and nucleus/coating thickness ratio, differentiate three main types of coated grains, with transitions between them.

a. Ooids are spherical grains commonly between 0.1 and $2 \mathrm{~mm}$ in diameter. They have a nucleus of micrite, bioclasts or detrital grains or in cases they lack any nucleus. The coating is thicker and more prominent than the nucleus and consists of well-defined, concentrically arranged envelopes of varied textures and composition. The most common coatings are composed of an alternation of darker/ligher micrite laminae (Fig. 6E). Some ooids, especially in Gando show orange nuclei and laminae. The intensity of orange colour decreases from the nuclei to the outer envelopes indicating a decrease in iron content (Fig. 6F). Commonly the outer coatings are either more micritic or contain more oriented clays. Silt-sized detrital grains appear in some envelopes. In cases the lighter laminae are semi-isotropic, suggesting a mixed composition of calcite and amorphous Si-Mg-rich films (Fig. 6E), in cases giving some oriented birefringence. Other ooids consists of a crudely laminated very light coating, which is quasi isotropic under cross nichols but show some oriented clay coatings (Fig. 6G, H).

b. Surficial coated grains, mostly sand-sized, have very thin coatings in relation with the nucleus. They have usually 1-3 coatings, which are made of micrite with micro-peloids $(0.02 \mathrm{~mm})$, orange oriented clays and isotropic, probably $\mathrm{Mg}-\mathrm{Si}$ films (Fig. 7A, B). The coatings are in cases detached from the nucleus.

c. Pisoliths are larger coated grains a few $\mathrm{mm}$ to decimeters across. The nuclei are marine bioclastic sands, volcanic fragments or reworked calcrete fragments. The coatings are composed of cmthick laminated micrite as the described above (Fig. 7C). Pisoliths occur isolated within different horizons or forming individualized horizons mostly at the top of the profiles. In cases, such as in Punta de la Monja profile they appear reworked and broken.

7. Peloids occur in small patches, filling tubes or constituting most of the calcrete as in Cuesta de Silva profile, where in cases are laminated. The colour is from brown to grey. They are rounded to ovoidal and 50 to $150 \mu \mathrm{m}$ across. They are welded, loose or connected by micritic filaments, microbial tubes $(200 \mu \mathrm{m}$ long and $20 \mu \mathrm{m}$ in diameter) (Fig. 7D, E) or needle fibre calcite. Some of them have a thin carbonate coating. The peloids are formed by calcite crystals and contains some organic remains (Fig. 7F). In Cuesta de Silva profile the peloidal fabric substitutes the original groundmass.

8. Spherulites occur within the laminated micrite and ooid coatings they are about 10 to $20 \mu \mathrm{m}$ across, have fibro-radial textures and are lighter than the carbonate they are included. In cases, they seem to corrode the laminated micrite but also they are corroded and 


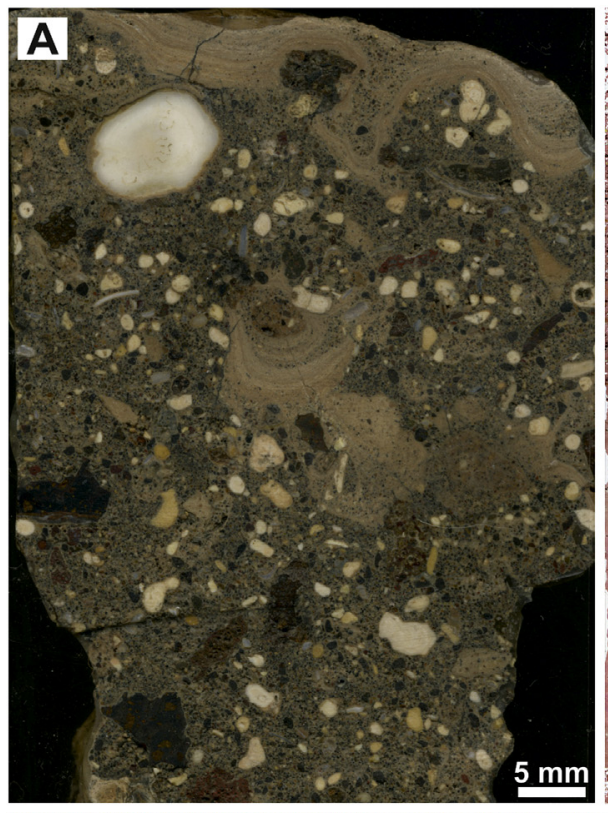

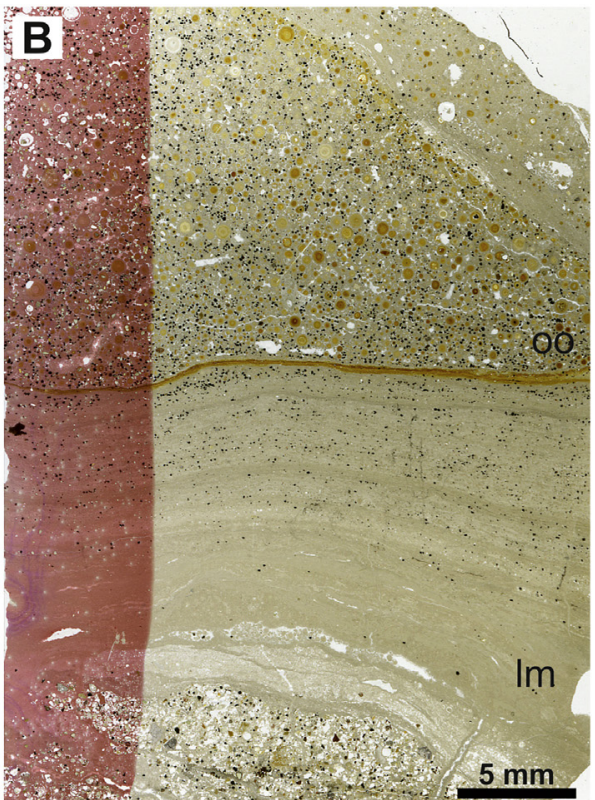

Fig. 5. A) Hand sample of one of the layers of Punta de la Monja profile. The host rock is volcanoclastic coarse-grained sand to gravel including large bioclast fragments (white fragments). The top is laminated micrite, which also appears coating some of the fragments mostly on the undersides. B) Thin section image of a thin laminar horizon from Gando profile. The laminated micrite $(\mathrm{lm})$ is interlayered with ooids layers (oo). The laminated micrite is composed of darker and lighter laminae and include volcanic grains (dark). C) Thin section of thinly laminated micrite showing darker (more micritic) laminae alternating with lighter laminae with ooids, micritic grains and thin micrite laminae. Ámbar profile. D) Desiccated micrite with a large amount of etched grains, some with thin micritic coatings. The cracks are very irregular and are empty. Playa del Cabrón profile. E) Fine crystalline dolomite from Playa del Cabrón profile containing coated grains, desiccation cracks and peloids. F) SEM view of the fine crystalline dolomite and calcite crystals that constitute the groundmass. Some larger dolomite rhombs are sparsely distributed.
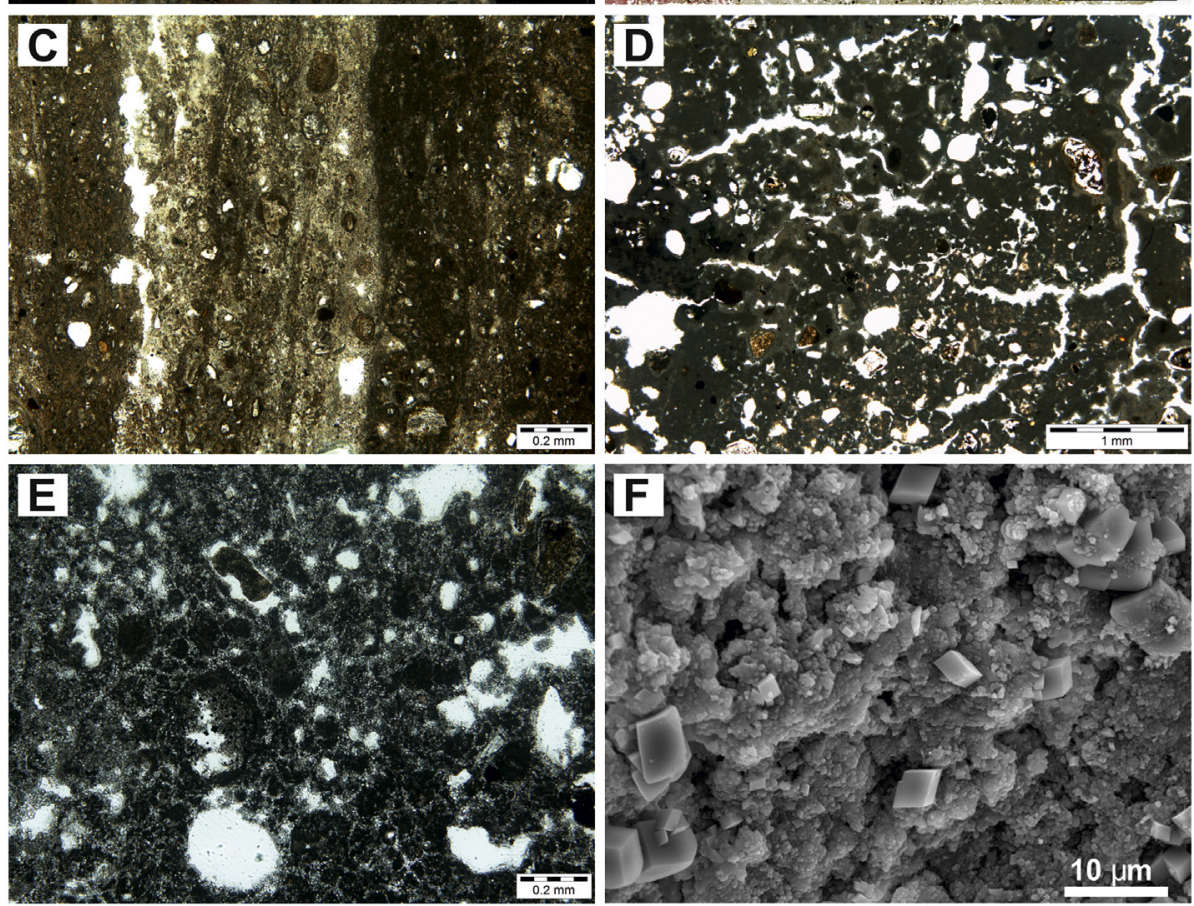

sometimes reworked.

\subsection{Isotope geochemistry: $\delta^{18} \mathrm{O}, \delta^{13} \mathrm{C}$ and ${ }^{87} \mathrm{Sr} /{ }^{86} \mathrm{Sr}$}

Carbon isotope values $\left(\delta^{13} \mathrm{C}\right)$ vary between -3.26 and $-7.29 \%$ VPDB in the overall samples except in Cuesta de Silva profile where they are lighter -8.02 to $-9.18 \%$ VPDB (Table 1). Oxygen values do not show differences within the profiles being comprised between +0.86 and $-3.24 \%$ VPDB. In Cabrón profile with samples constituted by calcite and dolomite, the dolomite part shows the heaviest values ranging from -4.39 to $-3.26 \%$ VPDB for $\delta^{13} \mathrm{C}$ and +0.86 to $-0.52 \%$ VPDB for $\delta^{18} \mathrm{O}$. Overall samples show a positive linear trend $\left(\mathrm{R}^{2}=0.45\right.$; if Cuesta de Silva samples are excluded, $\left.\mathrm{R}^{2}=0.81\right)$ between $\delta^{18} \mathrm{O}$ and $\delta^{13} \mathrm{C}$ (Fig. 8).

Carbonate from the calcrete/dolocrete samples has ${ }^{87} \mathrm{Sr} /{ }^{86} \mathrm{Sr}$ ratios between 0.707504 and 0.708860 . Values from Cuesta de Silva show slightly lower values (Table 1. Fig. 9). The range is slightly narrower than that displayed by calcretes from the adjacent islands of Lanzarote and Fuerteventura (Huerta et al., 2015). Samples of aeolian dust show ${ }^{87} \mathrm{Sr} /{ }^{86} \mathrm{Sr}$ ratios vary from 0.707819 to 0.710237 .

\section{Discussion}

\subsection{Calcrete profiles interpretation}

The studied profiles show an enormous variety of macro and microfeatures, relatively common in calcretes. Others are less commonly described, such as horizons constituted mostly of peloids or ooids, the quasi-isotropic coatings of some the ooids, the large peloids or the presence of dolomite. Here we interpret the different horizons together with their main microfeatures.

Prismatic horizons are somehow different to the commonly described horizons in which vertical columnar peds form the whole bed/ horizons (Esteban and Klappa, 1983; Casado et al., 2018). Here, the 

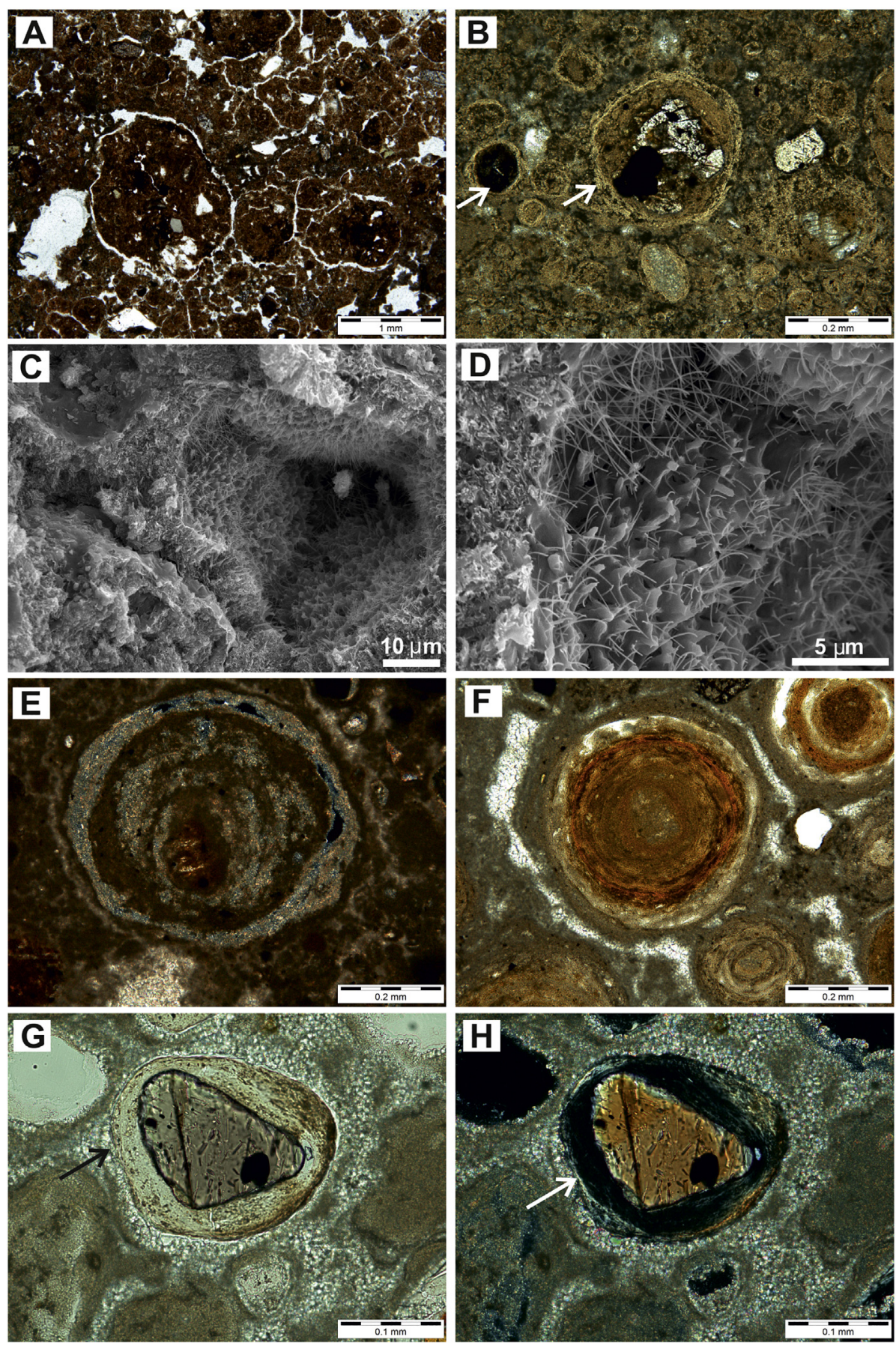

Fig. 6. A) Cuesta de Silva profile, groundmass of micrite and clays with desiccation cracks and etched detrital grains. B) Oriented clay coatings in Punta de la Monja Profile (arrowed). C) SEM view of clay coatings in Cuesta de Silva profile, probably smectites. The grain is detached leaving moldic porosity. D) Detailed view of $\mathrm{C}$, showing the spiky/fibrous morphology of the clays with a very open arrangement. E) Ooid form Punta de la Monja profile formed by an alternation of micrite and clay-rich laminae. Crossed nichols. F) Ooids from Gando profile, the variation in the laminae colour is due different amounts of clay, micrite and iron. The external laminae seem to be more micritic. $\mathrm{G}$ and $\mathrm{H}$ ) Coated grains with isotropic laminated envelopes. Parallel (G) and cross-nichols (H). Playa del Cabrón profile. prisms are commonly isolated within the host rock. The origin of the prismatic horizons has been attributed to carbonate precipitation around roots driven by microbial and root activity (Esteban and Klappa, 1983; Alonso-Zarza and Arenas, 2004), as seen in the formation of rhizoliths and megarhizoliths (Calvet et al., 1975; Alonso-Zarza et al., 2008; Alonso-Zarza and Casillas, 2019). Downward water movements controlled or not by vertical root systems could favour the formation of these vertically oriented carbonate nodules (Alonso-Zarza and Wright, 2010). However, in the study case, some features of these horizons are not fully understood, such as: i) the presence of horizontal cracks, ii) the lack in many cases of well-preserved biogenic features, or iii) the similar width of the prisms along the same horizon. The horizontal cracks may reflect heterogeneities of the host rock, such as lamination or less replaced layers that later enlarged by desiccation. In the study cases, most of the cracks are empty, but in other cases, these cracks were conduits for water enabling the presence of oriented clays and calcified roots (Casado et al., 2014). Biogenic features are relatively well preserved in rhizoliths and megarhizoliths formed in aeolian sands, where coated grains and alveolar septal structures are common (Calvet et al., 1975; Alonso-Zarza et al., 2008). However, very probably, the origin of the prisms is not the same as the rhizoliths for several reasons. Most of the prismatic horizons developed in clay-rich substrates, where water movement is more difficult than in sands, and the effect of increasing grain packing is lower. Carbonate precipitation could start in one point both by biogenic and abiogenic processes and the nodules continue to grow centrifugally. Therefore, the rarity of preserved biogenic features is because the prisms did not only form by biogenic processes, and water circulation enhanced transformation processes within the primary carbonate and the loss of some of the biogenic features. The similar width of the prisms is not easy to explain, although it is possibly 

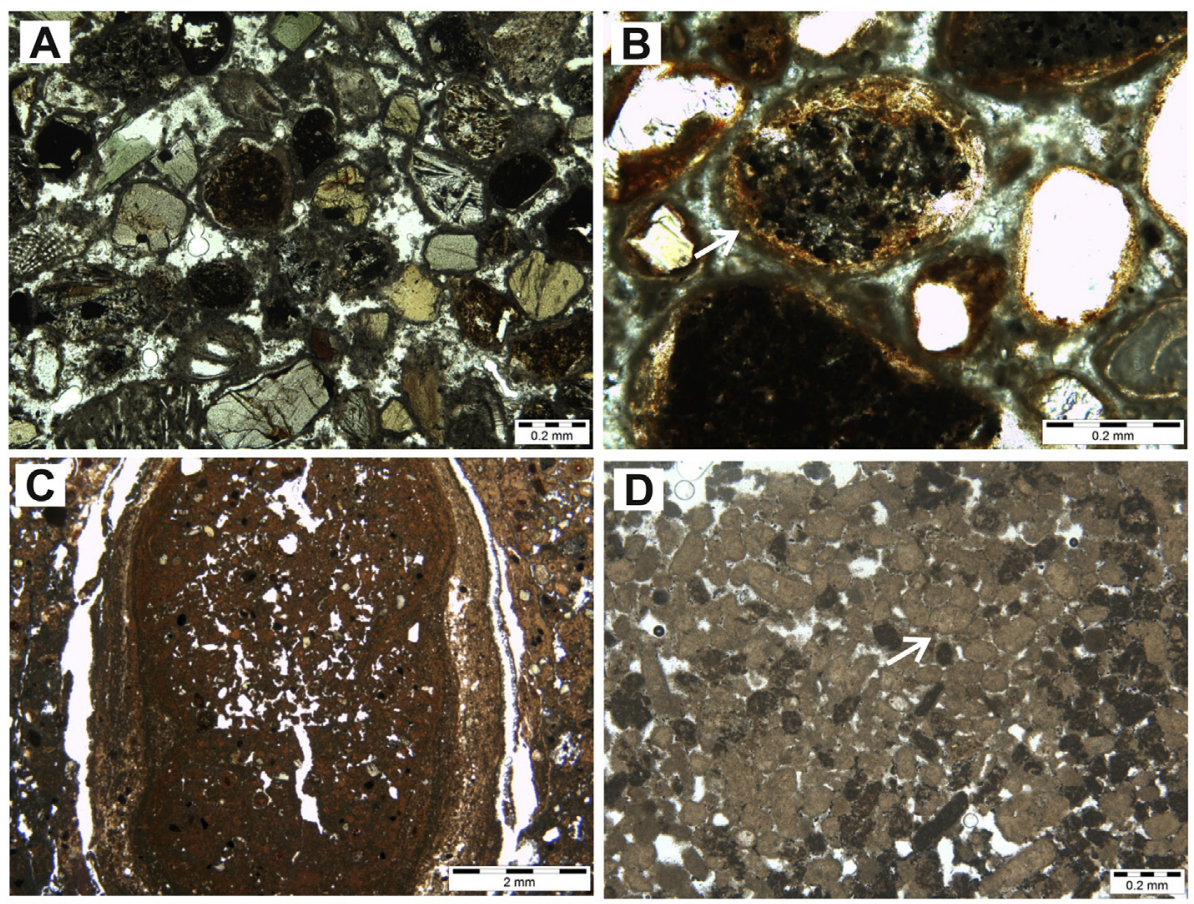

Fig. 7. A) Surficial coated grains with a thin micritic envelope. The grains are bioclasts, quartz and volcanic fragments. Ámbar profile. B) Surficial coated grains in this case there is a first clay envelop followed by a thin micritic one. The grains include bioclasts, quartz and volcanic fragments. Playa del Cabrón profile. C) Small pisolith consisting of a nucleus formed by micrite with ooids and desiccation cracks surrounded by laminated micrite. Monja profile. D) Peloids in Cuesta de Silva profile constitute an important part of the carbonate laminae. They are very well sorted, mostly micritic and have a thin darker envelope (arrowed). E) Close-up view of some of the peloidal laminae form Cuesta de Silva profile. The peloids are very irregular, some are amalgamated and micritic tubes connect some of them (arrowed). F) SEM view of one of the peloids composed by micrite crystals, but some organic remains are preserved (arrowed).
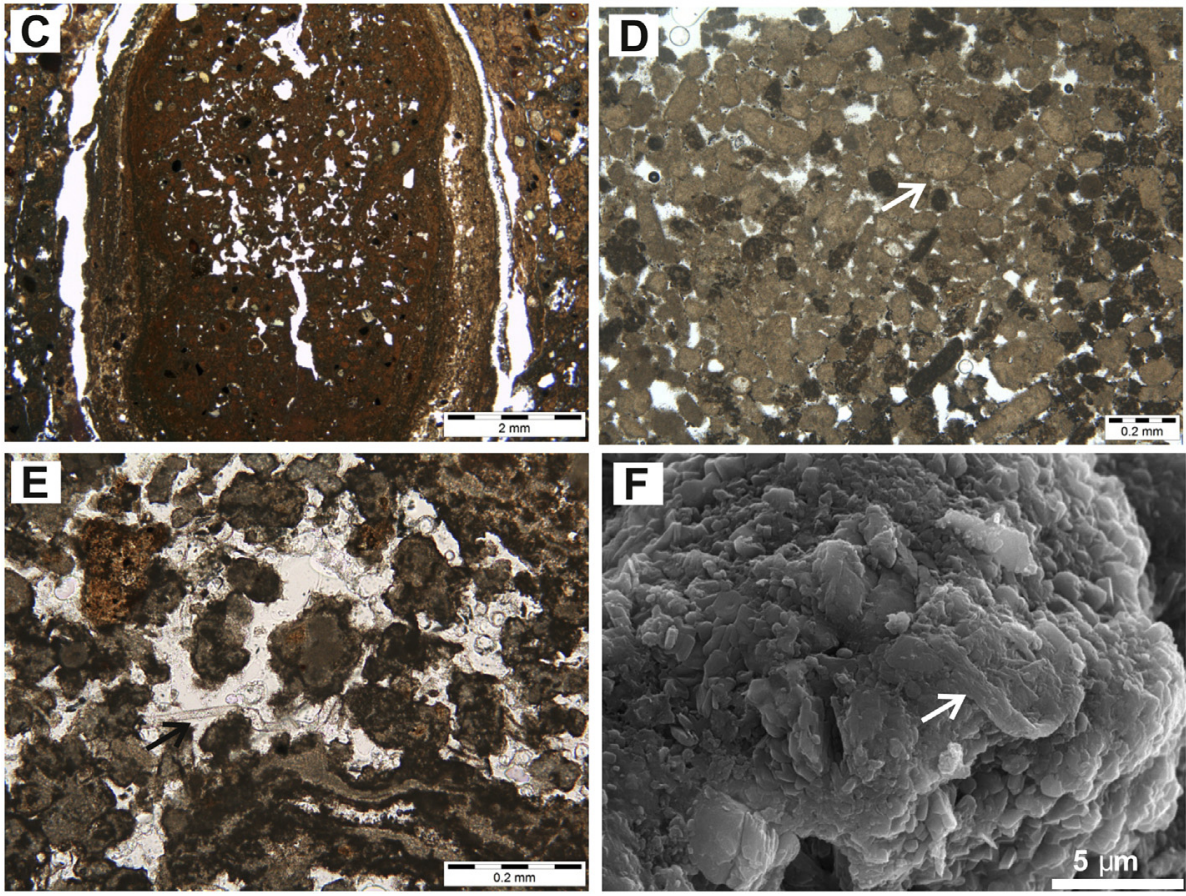

controlled by the area of root influence and by the distribution of water and solutes around the carbonate nucleation site.

Massive horizons are constituted by fine crystalline calcite and/or dolomite, including etched grains and clays. It is noticeable that although calcite dominates, dolomite is significant in Playa del Cabrón profile. Most of micrite and/or dolomicrite replaced the volcanic host rock, the gravels, or the soils. The interlayering of the massive horizons between laminar or ooid-rich horizons suggests a dominant vadose setting. The micritic filaments and the peloids indicate the biogenic influence on the formation of these massive horizons, whereas the cracks, the etched detrital grains and the coarser size of the dolomite indicate the dominance of physico-chemical processes (Singh and Lee, 2007; Meléndez et al., 2011).

Dolomite-rich patches and horizons in Playa del Cabrón profile are interlayered with calcite ones (massive or not) and replace the desiccated micrite, preserving their texture, but showing coarser (dolomicrospar) crystal size. This differs from others profiles from the Canary Islands where dolomite formed earlier than calcite or at greater depths of the profiles (Alonso-Zarza et al., 2016; Diaz-Hernandez et al., 2018). The main dolomite texture, the dolomicrospar, lacks some of the characteristic features of primary biogenically induced dolomite in soils, such as nearby root structures or calcified cells (Casado et al., 2014). In the study case dolomite formed soon after calcite precipitation, induced by the increase in the $\mathrm{Mg} / \mathrm{Ca}$ ratio of the vadose or phreatic waters due to former calcite precipitation within the soil. The presence of these dolomite-rich horizons near the coast, and the isotopic values of the dolomite, heavier than those of calcite suggest a source of water isotopically heavier than evolved meteoric water, such as seawater, similar to the described in the middle Devonian of Alberta (Williams and Krause, 1998), which also could supply the magnesium. The setting of formation of these dolomite-rich calcretes is different of those commonly described as a result of the evolution of groundwater to reach evaporitic conditions in terminal basin settings (Colson and Cojan, 1996; Jutras et al., 2011; Jutras, 2017) or as a result of the emerging groundwater also under evaporitic conditions (Mather et al., 2019). The scarce spheroidal dolomite found mostly cementing voids of the volcanic fragments is probably the first dolomite phase formed, as in Mirador del Rio profile in Lanzarote, where the initial weathering of the basalts could produce locally enriched Mg-solutions favoring dolomite formation (Capo et al., 2000; Whipkey et al., 2002; Whipkey and Hayob, 2008) as a cement (Alonso-Zarza et al., 2016).

The three scales of laminar horizons reflect different order processes of soil formation and even different environments. The thickness and the characteristic of the horizons depend on the time that the root mat systems are active, controlling carbonate precipitation within soil horizons (Alonso-Zarza and Wright, 2010), and their interplay with sedimentation and erosion processes, which can be repeated over time (Alonso-Zarza et al., 1998; Meléndez et al., 2011). The thicker profiles are similar to the commonly described laminar or rhizogenic calcretes or rootcretes (Wright et al., 1988; Jones, 1992; Wright et al., 1995) in which phases of soil formation, sedimentation and erosion process may be repeated over long periods. The formation, and in other cases the overlapping of these thick profiles are probably indicators of large scale climatic/vegetation changes (Alonso-Zarza and Silva, 2002). The 
Table 1

$\delta^{18} \mathrm{O}_{\text {VPDB }}, \delta^{13} \mathrm{C}_{\text {VPDB }}$ and ${ }^{87} \mathrm{Sr} /{ }^{86} \mathrm{Sr}$ values of Gran Canaria calcretes and aeolian dust.

\begin{tabular}{|c|c|c|c|c|c|}
\hline & \multicolumn{2}{|l|}{ CALCITE } & \multicolumn{2}{|c|}{ DOLOMITE } & \multirow[b]{2}{*}{${ }^{87} \mathrm{Sr} /{ }^{86} \mathrm{Sr}$} \\
\hline & $\begin{array}{l}\delta^{13} \mathrm{C}(\mathrm{V}- \\
\mathrm{PDB})\end{array}$ & $\begin{array}{l}\delta^{18} \mathrm{O}(\mathrm{V}- \\
\mathrm{PDB})\end{array}$ & $\begin{array}{l}\delta^{13} \mathrm{C}(\mathrm{V}- \\
\mathrm{PDB})\end{array}$ & $\begin{array}{l}\delta^{18} \mathrm{O}(\mathrm{V}- \\
\mathrm{PDB})\end{array}$ & \\
\hline \multicolumn{6}{|l|}{ Calcretes } \\
\hline AMB-1 & -5.00 & -1.66 & -3.88 & -1.27 & \\
\hline AMB-2 & -5.96 & -2.25 & & & \\
\hline AMB-3 & -6.18 & -2.25 & & & \\
\hline AMB-4 & -5.83 & -2.35 & & & \\
\hline AMB-5C & -6.38 & -2.08 & -3.10 & -0.31 & 0.708789 \\
\hline AMB-6 & -5.66 & -2.84 & & & \\
\hline CAB-1C & -4.02 & -0.42 & -3.60 & 0.47 & \\
\hline CAB-2 & & & & & 0.707894 \\
\hline CAB-3 & -5.14 & -1.39 & -3.72 & 0.56 & \\
\hline $\mathrm{CAB}-4$ & -3.00 & 0.89 & -3.69 & 0.86 & \\
\hline CAB-5 & -3.54 & 0.76 & -4.29 & 0.49 & \\
\hline CAB-6AC & -5.61 & -2.62 & -3.26 & -0.27 & \\
\hline CAB-6B & -2.51 & 0.65 & -3.35 & 0.82 & \\
\hline CAB-7A & -4.82 & -1.46 & & & \\
\hline CAB-7B & -5.30 & -1.61 & & & 0.707504 \\
\hline CAB-8 & -5.97 & -2.18 & & & \\
\hline CAB-9A & -3.75 & 0.08 & -3.94 & 0.34 & \\
\hline CAB-9B & -4.77 & -1.04 & -4.39 & -0.52 & \\
\hline GAN SUR 1 & -4.94 & -1.74 & -2.62 & -0.67 & \\
\hline GAN SUR 2 & -6.78 & -2.92 & -3.98 & -1.19 & 0.708775 \\
\hline GAN SUR 3 & -6.56 & -2.99 & -5.67 & -2.37 & 0.708571 \\
\hline GAN SUR 4 & -6.80 & -3.40 & & & \\
\hline GAN SUR 5 & -6.68 & -2.96 & -4.15 & -1.26 & \\
\hline GAN SUR 6 & -7.30 & -3.06 & -7.18 & -2.76 & \\
\hline GAN SUR 7M & -6.16 & -1.85 & -3.91 & -0.48 & \\
\hline GAN SUR 7V & -6.67 & -2.33 & -4.28 & -0.86 & \\
\hline GAN SUR 8 & -6.70 & -2.88 & -4.46 & -0.79 & \\
\hline GAN SUR 9 & -5.30 & -1.33 & -4.25 & -0.66 & \\
\hline GAN SUR 10C & -5.97 & -1.96 & & & 0.708860 \\
\hline GAN SUR 10M & -4.19 & -0.31 & -4.03 & 0.63 & \\
\hline MONJ-1A & & & & & 0.708714 \\
\hline MONJ-3C & & & & & 0.708722 \\
\hline MONJ-1B & -4.19 & -0.52 & & & \\
\hline MONJ-5AM & -3.93 & -1.43 & & & \\
\hline MONJ-6AC & -3.83 & -0.65 & & & \\
\hline SIL-1 & -8.02 & -1.20 & & & \\
\hline SIL-5 & -9.15 & -1.82 & & & 0.707576 \\
\hline SIL-MASIVA & -9.11 & -1.51 & & & \\
\hline SIL-RAICES & -9.18 & -2.28 & & & 0.707516 \\
\hline \multicolumn{6}{|l|}{ Aeolian dust } \\
\hline GANDO 7/10/04 & & & & & 0.708323 \\
\hline TALI 13/10/06 & & & & & 0.707819 \\
\hline TARIFA BAJA V17 & & & & & 0.708084 \\
\hline TARIFA BAJA V18 & & & & & 0.710237 \\
\hline TARIFA BAJA V19 & & & & & 0.708678 \\
\hline
\end{tabular}

intermediate scale laminar horizons formed by installation and later calcification of root mats, in relatively short-lived stable surfaces. The varied microfabrics of the laminated micrite indicate small-scale alternation of erosion, sedimentation and carbonate precipitation (Fedoroff et al., 1994), probably controlled by climate-vegetation changes as seen in the intermediate part of Punta de la Monja profile and in the base of Gando. Carbonate precipitation would occur in the relative more humid periods, whereas the arid periods would favour erosion and sedimentation. The carbonate in the laminae precipitated by a variety of processes including biogenic precipitation within the rhizosphere either by the roots or its associated microorganisms (calcified filaments, ooids and spherulites) or merely physicochemical (micrite and microspar) (Meléndez et al., 2011; Eren et al., 2018). The pseudo-anticline structures and the cracks were the result of mostly horizontal root penetration in very surficial, previously formed laminar horizons. However, the displacive growth of calcretes also contributed to horizontal expansion and deformation of the calcrete sheets, and in cases together with root penetration could result in the brecciation and

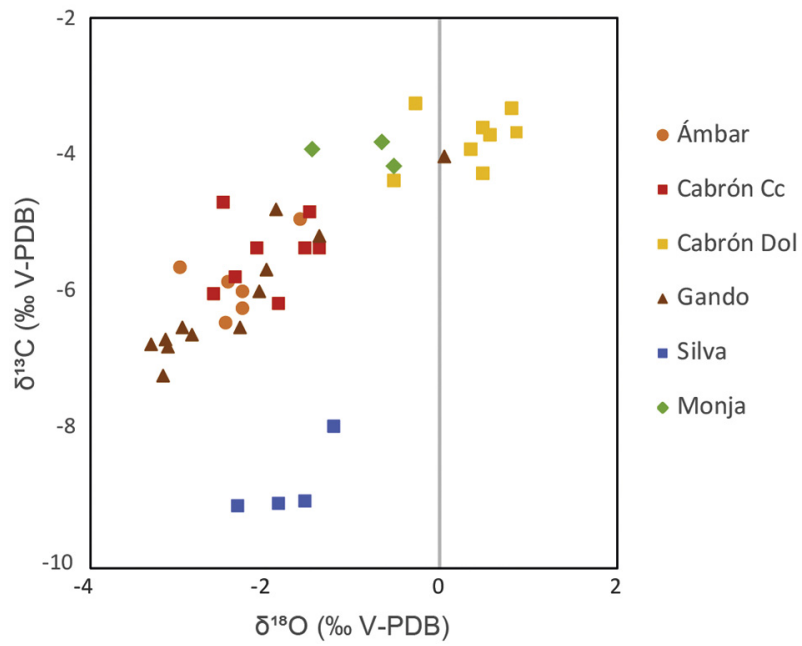

Fig. 8. $\delta^{18} \mathrm{O}_{\mathrm{VPDB}}$ and $\delta^{13} \mathrm{C}_{\mathrm{VPDB}}$ values from Gran Canaria calcretes. Most of them are obtained in calcite, except Cabrón that include calcite and dolomite.

destruction of previous horizons (Watts, 1977; Klappa, 1980), forming brecciated horizons. The root-mats penetrated the discontinuities or created them (Alonso-Zarza and Jones, 2007; Borges et al., 2016; Alonso-Zarza, 2018), and later these cavities were coated by discontinuous calcified root-mats forming thin laminar crusts.

Pisoliths as those of Ámbar profile with a nucleus of loose sands, formed during incipient stages of calcrete formation as shown by the amount and distribution of carbonate. The individualization of the large sand areas could be due to loss of water of the clay matrix and/or root penetration. Root-mats coated the fragments and formed thin laminar crusts around these fragments but also on volcanic fragments or bioclasts. Of special interest is the presence of pisoliths whose nuclei consist of reworked calcrete fragments. In this case the individualization of the nuclei requires the brecciation of previous calcrete horizon by roots, displacive growth of calcretes and even desiccation. This is a common process in well-developed calcretes and reflects the multiple cycles of calcrete formation and brecciation (Wright and Tucker, 1991; Meléndez et al., 2011).

Sandy mudstones horizons with rhizoliths formed by bio and physico-chemically replacement of the host rock by carbonate and by root calcification. Sandy mudstones may appear at different situations within the profiles. They indicate the reactivation of sedimentation and the decrease of calcrete formation processes as seen in Gando profile. These horizons are probably the previous stages of the formation of the massive horizons with the increasing of carbonate precipitation as indicated by the preservation of clays within the groundmass (micriteclay groundmass). The presence of root and insect traces as well as the grilled-structure (Bustillo et al., 2013) outline the significance of biogenic processes in the formation of these horizons but the displacement and strong corrosion of some grains, and the presence of some spar cements point also to non-biogenic processes (Braithwaite, 1989).

In ooid-bearing horizons the different composition of the nucleus and envelopes of the ooids indicate the complexity of the processes involved in their formation. The nuclei could be initially separated or isolated within the soil (fragments of host rock or sediments) or be isolated due to mechanical of biological processes (micritic nuclei), as described in calcretes and palustrine limestones (Mazzullo and Birdwell, 1989; Alonso-Zarza et al., 1992; Armenteros and Daley, 1998; Miller and James, 2012). The presence of fine detrital grains indicates that the ooids rolled within the soil and incorporated by adhesion the soil loose material, either grains or clays, the latter could be oriented tangentially and then show some birefringence, which could be also due to clay illuviation. The rolling of the grains, the oriented clays (Hay and Reeder, 1978; Hay and Wiggins, 1980) and the common presence of 


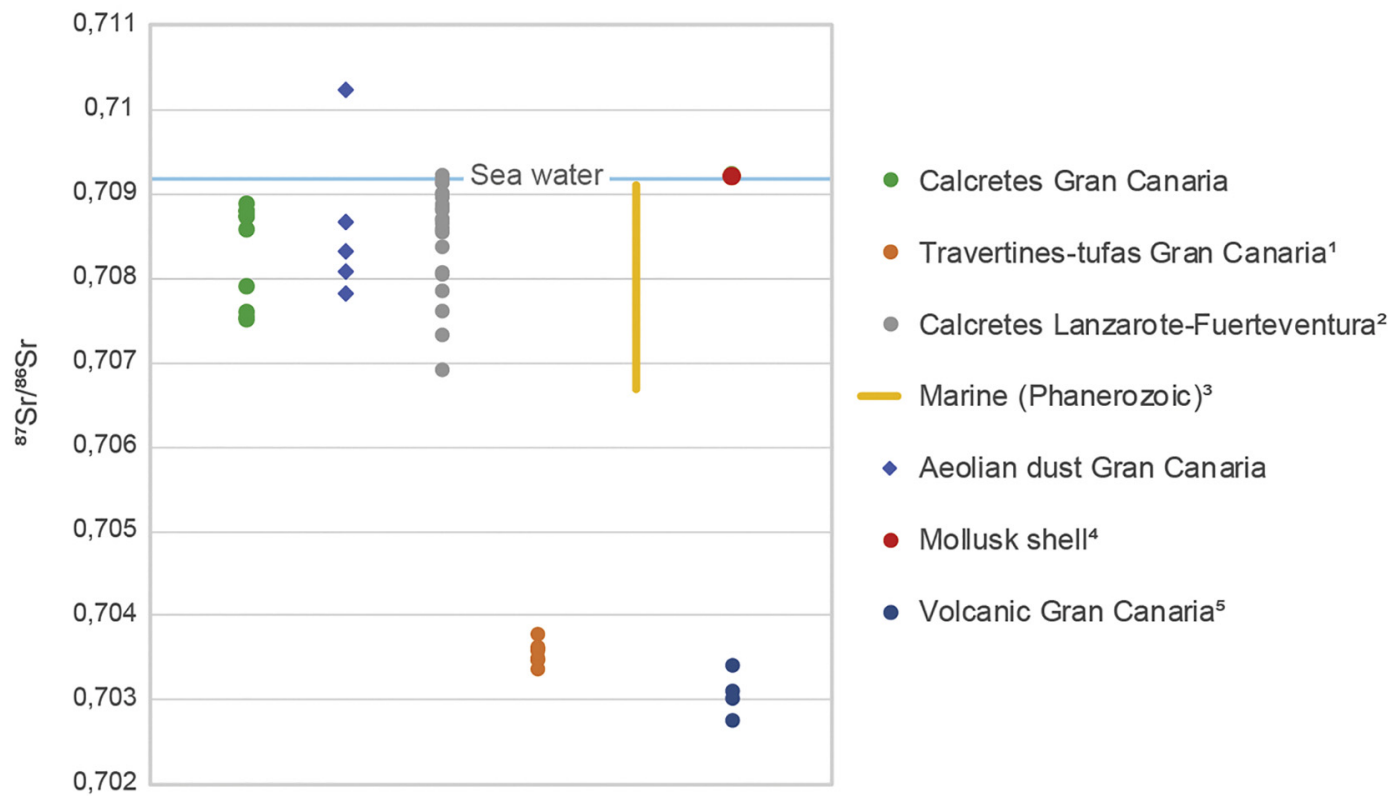

Fig. 9. ${ }^{87} \mathrm{Sr} /{ }^{86} \mathrm{Sr}$ values of Gran Canaria calcretes, aeolian dust and comparison with: (1) travertine-tufas from Gran Canaria (Rodríguez-Berriguete and Alonso-Zarza, 2019), (2) calcretes from Lanzarote and Fuerteventura (Huerta et al., 2015), (3) Phanerozoic marine carbonates (Burke et al., 1982), (4) mollusk shells from Tenerife and Madeira Islands (Kuznetsov et al., 2012), and (5) volcanic rocks from Gran Canaria (Aulinas et al., 2010).

insect traces in these calcretes suggest that not only roots but also insects may have a role in ooid formation moving the ooids and material from the soil (Alonso-Zarza and Silva, 2002). The micritic envelopes and their thin alternation reflect slightly different precipitation conditions probably controlled by the relationship between biogenic and abiogenic processes. The lighter semi-isotropic laminae containing $\mathrm{Si}-\mathrm{Mg}$ films were either decaying EPS (extracellular polymeric substances) or inorganic gels. The relatively thick coatings and the rarity of biogenic features point to the second possibility. The weathering of volcanic rock can easily give place to $\mathrm{Si}-\mathrm{Mg}$-rich solutions that later can form $\mathrm{Si}-\mathrm{Mg}$ films. These ooids occur in the calcretes from Playa del Cabrón, containing dolomite, so their cortices and the dolomite reveal more alkaline Si-Mg-rich solutions within the calcretes than in the other profiles. These $\mathrm{Mg}-\mathrm{Si}$ films could also play a role in dolomite precipitation (Díaz-Hernández et al., 2013; Martín-Pérez et al., 2015).

Reworking and rounding of the micrite groundmass may lead to peloid formation. However, peloids from the studied calcretes are mostly biogenic, either fecal pellets, or aggregations of different microbial components (Alonso-Zarza, 2018) as shown by the presence of several biogenic features (Fig. 7F). Cuesta de Silva profile shows how the initial soil fabric is replaced by the peloids indicating the role of living organisms (fauna, plant roots or microbes) in their formation.

Clays in these profiles are either relics of former sediments or soils that in most cases are being replaced by the calcrete carbonate. Clay coatings on grains and voids suggest illuviation processes in the soil profile with rearrangements of clays. In addition, in Cuesta de Silva profile where clays show very open arrangement and spiky morphology they can directly formed in the calcretes either by transformation of former clays, $\mathrm{Si}-\mathrm{Mg}$ films or as a void-filling precipitate.

The profiles are varied and it is not possible to stablish a typeprofile. In general, there are two main types. The first one includes the base of Punta de la Monja or top of Playa del Cabrón calcrete where massive, prismatic and laminar horizons amalgamate to form thick calcrete profiles. In the second type, calcrete horizons are separated by different type of sediments/host rock, as at the top of Monja, base of Gando or Cuesta de Silva profiles.

In the first type, periods of very low sedimentation rate favored the amalgamation of the laminae, which together with a possible influence of groundwater may result in compact and thick calcrete profiles. In the second type, higher sedimentation rates allowed the separation of the different calcrete horizons and even the preservation of the thin rootmats, as in Cuesta de Silva. In addition, erosion driven by long periods of non-sedimentation, non-calcrete formation resulted in the reworking and in the presence of large fragments of pisoliths included in the base of some calcretes sequences. Both types of profiles are complex and record different ratios sedimentation/calcrete formation/erosion proceses (Alonso-Zarza, 2003; Alonso-Zarza and Wright, 2010) because of climate, vegetation or aeolian dust input changes through time.

As a difference of most contexts in which sedimentation is mostly fluvial (Marriott and Wright, 1993; Alonso-Zarza et al., 1999; Kraus, 1999) here the sediments interbedded with the calcretes are mostly aeolian or marine and so the calcretes/sediment relationship could also be indicators of sea-level and environmental changes with precise chronology if the calcretes could be dated.

\subsection{Controls on calcrete profile distribution and development}

The location of the main volcanic building in the center of the island conforms the circular-conical morphology of Gran Canaria and gives an overall radial altitude decrease from the center to the coast, controlling so the different relief, climate, vegetation and aeolian dust/calcium supply areas along the Island, leaving their imprint in the calcretes.

Strontium ratio of pedogenic carbonates is a good indicator of calcium provenance, via external input or by in situ weathering of host rocks (Capo et al., 1998). Gran Canaria calcretes and aeolian dust have similar ${ }^{87} \mathrm{Sr} /{ }^{86} \mathrm{Sr}$ ratios and fit within the range of marine ${ }^{87} \mathrm{Sr} /{ }^{86} \mathrm{Sr}$ ratios for the Phanerozoic (Burke et al., 1982; Prokoph et al., 2008), and are slightly lower than the strontium isotope ratios of recent marine bioclasts (Table 1. Fig. 9). The strontium isotope ratios clearly differ from those of the volcanic rocks and tufa/travertine deposits from Gran Canaria Island (Cousens et al., 1990; Ovchinnikova et al., 1995; Thirlwall et al., 1997; Abratis et al., 2002; Hansteen and Troll, 2003; Aulinas et al., 2010a, 2010b; Rodríguez-Berriguete and Alonso-Zarza, 2019). Thus, weathering of the volcanic rocks or volcanic clasts was not the main calcium source. The main sources to be considered are aeolian dust and marine bioclasts. In Gran Canaria, marine bioclasts do not appear in all the horizons/profiles. There are no bioclasts in Cuesta de Silva and still the ${ }^{87} \mathrm{Sr} /{ }^{86} \mathrm{Sr}$ ratios are close to the range of those of the 
aeolian dust. ${ }^{87} \mathrm{Sr} /{ }^{86} \mathrm{Sr}$ ratios of Lanzarote and Fuerteventura calcretes, are similar to those of Gran Canaria, but have a wider range as the studied profiles developed in wider variety of substrates, with slightly higher ${ }^{87} \mathrm{Sr} /{ }^{86} \mathrm{Sr}$ ratios in profiles developed in substrates with marine bioclasts (Huerta et al., 2015). In short, in the three islands the strontium isotope ratios in all of the profiles fits well with a main aeolian supply from the Mesozoic carbonates of the Atlas region (Hamidi et al., 2001), but with a minor and local contribution of marine bioclasts. The slightly lower ${ }^{87} \mathrm{Sr} /{ }^{86} \mathrm{Sr}$ ratios of Cuesta de Silva profile (situated at the north and higher altitude) suggest some minor contribution of the volcanic sourced calcium, probably through weathering processes. In the study case, the dust coming from the Sahara deposits preferably in the eastern areas of the island and also at low altitudes (Menéndez et al., 2007) supplied calcium rich particles to the soil surface (Muhs et al., 2010; Criado et al., 2011; Scheuvens et al., 2013).

The profiles show macro and microfabrics clearly controlled by biogenic processes such as the ooids, peloids, alveolar structures, filaments, prismatic horizons, rhizoliths or laminar structures and cracks, which together with the arrangements of the horizons indicates that these calcretes are mostly pedogenic (Wright and Tucker, 1991; Wright, 2007) with some influence of groundwater especially in the massive horizons. However, under SEM only some organic features are preserved, probably because the calcretes were not buried and thus the organic remains could be easily oxidized.

The location of the calcretes was not only controlled by the preferably settling of aeolian dust in the eastern areas, but also by relief, climate and vegetation, which are closely related. The better developed calcretes appear in the lowland and drier areas, with sparse vegetation at present. Higher, wetter and more vegetated areas inhibited large calcrete development and thus, thin profiles appear in northern areas such as in Cuesta de Silva or the thin root-mats observed sparsely along the island in relatively low, poor vegetated areas.

Previous studies have shown that in the eastern Canary Islands calcretes formed in the relatively humid and warm periods of a relatively dry climate (Danmati, 1997; Meco, 2008). The $\delta^{18} \mathrm{O}$ and $\delta^{13} \mathrm{C}$ (Fig. 8) are in the same range than the values from Lanzarote and Fuerteventura (Huerta et al., 2015; Alonso-Zarza et al., 2016), with $\delta^{18} \mathrm{O}$ being heavier than most pedogenic calcretes from Europe or Asia (Adamson et al., 2015; Khadkikar et al., 2000) reflecting the heavier values of rain water in eastern Canary Islands (Yanes et al., 2008). The $\delta^{13} \mathrm{C}$ values would reflect differences in the relative amount of $\mathrm{C}_{3}$ versus $\mathrm{C}_{4}+$ CAM plants and density of vegetation (Quade et al., 1989; Tanner, 2010). The correlation trend of $\delta^{18} \mathrm{O}$ and $\delta^{13} \mathrm{C}$ values is clear for the profiles of the eastern areas of the island (Monja, Cabrón, Ámbar and Gando). The trend reflects that both values evolved under similar environmental controls, which was probably climate and its influence on vegetation, as in some soils from the Mediterranean areas (Candy et al., 2012; Adamson et al., 2015). In the eastern areas vegetation is dominated by halophilous and xerofilous species which explain the relatively heavier values of these calcretes. The varied isotope values of the different profiles along the trend indicate either slightly different climate/ vegetation, or differences in the mechanism (more or less biogenic influence) of carbonate precipitation. The trend also points that the influence of carbonate derived from marine sources is limited as the amount of bioclastic components from the substrate is very variable in the different profiles and horizons. Within Playa del Cabrón profile the heavier values of the dolomite samples are not only due to the fractionation effect (O'Neil and Epstein, 1966) but also to the interplay of more evaporated or the mix of meteoric and marine groundwaters. A possible marine influence is seen in the presence of dolomite in Cabrón and Monja profiles, where the textures strongly suggest the initial formation of groundwater dolomite and probably some silica-rich coatings/cements on the volcanic fragments, which are absent in other areas lacking groundwater features. The values from Cuesta de Silva profile, constituted mostly of calcifed root-mats, are significantly lower and reflect the main role of plants and microbes in calcite precipitation, which fits well with the situation of this profile at higher altitudes more vegetated areas.

\section{Conclusions}

Gran Canaria Island contains a suite of calcretes whose varied profiles, textures and geochemistry reveal the complex interaction of a wide number of factors operating at the surface of volcanic islands. ${ }^{87} \mathrm{Sr} /{ }^{86} \mathrm{Sr}$ ratios of calcretes indicate that calcium is mostly supplied by aeolian dust and so determined the location of most calcretes in the eastern areas of Gran Canary.

The multi-storey calcretes include prismatic, massive, laminar, pisolithic, ooid-rich, sandy mudstones and brecciated horizons, constituted by laminated and desiccated micrite, fine crystalline dolomite, micrite-clay groundmass, oriented clay coatings, coated grains, peloids and some spherulites. The characteristics of the profiles and their micromorphology indicate that they are pedogenic calcretes developed under a strong biological control, although clearly biogenic features are rarely preserved. The detailed analysis of the profiles shows the interplay of sedimentation/erosion and pedogenesis processes in both long and short-term sequences of calcrete formation. Thick amalgamated laminar horizons indicate that calcretization rates were higher than sedimentation, whereas the interfingering of sediment suggests more active sedimentation.

Vegetation and climate controlled the situation of calcretes in the relatively arid and lowland areas. Carbon and oxygen isotope values show a good covariance trend because of the temperature/evaporation control on precipitation. Although most of the features are pedogenic, groundwater with a probably mix of marine waters accounted for the formation of some features and probably also of the dolomite and the Mg-Si-rich coatings.

Gran Canaria Island can be considered as a microcontinent in which its relief, vegetation, climate and aeolian input drive the distribution and characteristics of calcretes along the island. The lack of previous carbonate substrates in most of the island indicates that aeolian input is critical for calcrete formation.

\section{Declaration of Competing Interest}

The authors declare that they have no known competing financial interests or personal relationships that could have appeared to influence the work reported in this paper.

\section{Acknowledgements}

This work was financed by project CGL2014-54818 from Spanish Ministerio de Ciencia e Innovación. The work of AMP was supported by the Slovenian Research Agency project J1-9185. The Canary Islands Development Fund-FDCAN 2018 supported IM and JMV work. Ana Isabel Casado, Pedro Huerta, V.P. Wright and John Camuera are thanked for suggestions during fieldwork. We express our gratitude to V.P. Wright, an anonymous reviewer and the journal editor for their contribution to improve the paper.

\section{References}

Abratis, M., Schmincke, H.U., Hansteen, T., 2002. Composition and evolution of submarine volcanic rocks from the central and western Canary Islands. Int. J. Earth Sci. 91 (4), 562-582. https://doi.org/10.1007/s00531-002-0286-7.

Adamson, K., Candy, I., Whitfield, L., 2015. Coupled micromorphological and stable isotope analysis of Quaternary calcrete development. Quat. Res. 84 (2), 272-286. https://doi.org/10.1016/j.yqres.2015.05.002.

Alonso-Zarza, A.M., 2003. Palaeoenvironmental significance of palustrine carbonates and calcretes in the geological record. Earth-Sci. Rev. 60, 261-298. https://doi.org/10. 1016/S0012-8252(02)00106-X.

Alonso-Zarza, A.M., 2018. Study of a modern calcrete forming in Guadalajara, Central Spain: an analogue for ancient root calcretes. Sediment. Geol. 373, 180-190. https:// doi.org/10.1016/j.sedgeo.2018.06.006. 
Alonso-Zarza, A.M., Silva, P.G., 2002. Quaternary laminar calcretes with bee nests: evidences of small-scale climatic fluctuations, Eastern Canary Islands, Spain. Palaeogeogr. Palaeoclimatol. Palaeoecol. 178, 119-135. https://doi.org/10.1130/ 0016-7606(1998)110\%3C1304:MSOFCI\%3E2.3.CO;2.

Alonso-Zarza, A.M., Arenas, C., 2004. Cenozoic calcretes from the Teruel Graben, Spain: microstructure, stable isotope geochemistry and environmental significance. Sediment. Geol. 167, 91-108. https://doi.org/10.1016/j.sedgeo.2004.02.001.

Alonso-Zarza, A.M., Casillas, R., 2019. El Médano megarhizoliths field, Tenerife: Origin and paleoenvironmental significance. Geogaceta 65, 27-30.

Alonso-Zarza, A.M., Jones, B., 2007. Root calcrete formation on Quaternary karstic surfaces of Grand Cayman. Geol. Acta 5 (1), 77-88. https://doi.org/10.1344/105 000000311.

Alonso-Zarza, A.M., Silva, P.G., 2002. Quaternary laminar calcretes with bee nests: evidences of small-scale climatic fluctuations, Eastern Canary Islands, Spain. Palaeogeogr. Palaeoclimatol. Palaeoecol. 178, 119-135. https://doi.org/10.1016/ S0031-0182(01)00405-9.

Alonso-Zarza, A.M., Wright, V.P., 2010. Calcretes. In: Alonso-Zarza, A.M., Tanner, L.H. (Eds.), Carbonates in Continental Settings: Facies, Environments, and Processes. Developments in Sedimentology 61. Elsevier, Amsterdam, pp. 225-267. https://doi. org /10.1016/S0070-4571(09)06105-6.

Alonso-Zarza, A.M., Calvo, J.P., García del Cura, M.A., 1992. Palustrine sedimentation and associated features - grainification and pseudo-microkarst - in the Middle Miocene (Intermediate Unit) of the Madrid Basin, Spain. Sediment. Geol. 76, 43-61. https://doi.org/10.1016/0037-0738(92)90138-H.

Alonso-Zarza, A.M., Silva, P., Goy, J.L., Zazo, C., 1998. Fan-surface dynamics and biogenic calcrete development: Interactions during ultimate phases of fan evolution in the semiarid SE Spain (Murcia). Geomorphology 24, 147-167. https://doi.org/10. 1016/S0169-555X(98)00022-1.

Alonso-Zarza, A.M., Sopeña, A., Sánchez-Moya, Y., 1999. Contrasting paleosol development in two different tectonic settings: the Upper Buntsandstein of the Western Iberian Ranges, Central Spain. Terra Nova 11, 23-29. https://doi.org/10.1046/j. 1365-3121.1999.00218.x.

Alonso-Zarza, A.M., Genise, J.F., Cabrera, M.C., Mangas, J., Martín-Pérez, A., Valdeolmillos, A., Dorado-Valiño, M., 2008. Megarhizoliths in Pleistocene aeolian deposits from Gran Canaria (Spain): Ichnological and palaeoenvironmental significance. Palaeogeogr. Palaeoclimatol. Palaeoecol. 265 (1-2), 39-51. https://doi. org/10.1016/j.palaeo.2008.04.020.

Alonso-Zarza, A.M., Bustamante, L., Huerta, P., Rodríguez-Berriguete, Á., Huertas, M.J., 2016. Chabazite and dolomite formation in a dolocrete profile: an example of a complex alkaline paragenesis in Lanzarote, Canary Islands. Sediment. Geol. 337, 1-11. https://doi.org/10.1016/j.sedgeo.2016.02.018.

Del-Arco, M., Salas, M., Acebes, J.R., Del Marrero, M., Reyes-Betancort, J.A., Pérez-dePaz, P.L., 2002. Bioclimatology and climatophilous vegetation of Gran Canaria (Canary Islands). Ann. Bot. Fenn. 39 (1), 15-41.

del Arco, M., Wildpret, W., Pérez de Paz, P.L., Rodríguez, O., Acebes, J.R., García, A., Martí, V.E., Reyes, A., Salas, M., Díaz, M.A., Bermejo, J.A., González, R., Cabrera, M.V., García, S., 2003. Cartografía 1:25.000 de la Vegetación Canaria. GRAFCAN S.A. Santa Cruz de Tenerife 552 .

Armenteros, I., Daley, B., 1998. Pedogenic modification and structure evolution in palustrine facies as exemplified by the Bembridge Limestone (Late Eocene) of the Isle of Wight, southern England. Sediment. Geol. 119 (3-4), 275-295. https://doi.org/10. 1016/S0037-0738(98)00067-0.

Aulinas, M., Gimeno, D., Fernandez-Turiel, J.L., Font, L., Perez-Torrado, F.J., RodriguezGonzalez, A., Nowell, G.M., 2010a. Small-scale mantle heterogeneity on the source of the Gran Canaria (Canary Islands) Pliocene-Quaternary magmas. Lithos 119 (3-4), 377-392. https://doi.org/10.1016/j.lithos.2010.07.016.

Aulinas, M., Gimeno, D., Fernandez-Turiel, J.L., Perez-Torrado, F.J., Rodriguez-Gonzalez, A., Gasperini, D., 2010b. The Plio-Quaternary magmatic feeding system beneath Gran Canaria (Canary Islands, Spain): constraints from thermobarometric studies. J. Geol. Soc. Lond. 167 (4), 785-801. https://doi.org/10.1144/0016-76492009-184.

Balcells, R., Barrera, J.L., 1990. Mapa Geológico de España escala 1:25.000, $1^{\text {a }}$ edición (MAGNA), Hoja de Telde (84-84), Instituto Tecnológico Geominero de España (ITGE). Serv. Pub. $\mathrm{M}^{\circ}$ Industria, Madrid.

Balcells, R., Barrera, J.L., Gómez, J.A., Cueto, L.A., 1992. Mapa Geológico de España escala 1:100.000, $1^{\text {a }}$ edición (MAGNA), Hoja de la Isla de Gran Canaria (21-21/21 22). Instituto Tecnológico Geominero de España (ITGE), Serv. Pub. $\mathbf{M}^{\circ}$ Industria, Madrid.

Borges, S.V.F., Balsamo, F., Vieira, M.M., Iacumin, P., Srivastava, N.K., Storti, F., Bezerra, F.H.R., 2016. Pedogenic calcretes within fracture systems and beddings in Neoproterozoic limestones of the Irecê Basin, northeastern Brazil. Sediment. Geol. 341, 119-133. https://doi.org/10.1016/j.sedgeo.2016.05.012.

Bozzano, G., Kuhlmann, H., Alonso, B., 2002. Storminess control over African dust input to the Moroccan Atlantic margin (NW Africa) at the time of maxima boreal summer insolation: a record of the last 220 kyr. Palaeogeogr. Palaeoclimatol. Palaeoecol. 183, 155-168. https://doi.org/10.1016/S0031-0182(01)00466-7.

Braithwaite, C.J.R., 1989. Displacive calcite and grain breakage in sandstones. J. Sediment. Petrol. 59, 258-266. https://doi.org/10.1306/212F8F62-2B24-11D78648000102C1865D.

Burgoa-Torrontegui, I., Mangas, J., Sánchez-García, M.J., Quevedo-González, L., 2019. Análisis de procedencia de las arenas sumergidas y emergidas de cinco playas en la costa sur de Telde (E de Gran Canaria, España). In: Durán, R., Guillén, J., Simarro, G. (Eds.), X Jornadas de Geomorfología Litoral. Castelldefels, Barcelona, Spain, pp. 169-172.

Burke, W.H., Denison, R.E., Hetherington, E.A., Koepnick, R.B., Nelson, H.F., Otto, J.B., 1982. Variation of seawater ${ }^{87} \mathrm{Sr} /{ }^{86} \mathrm{Sr}$ throughout Phanerozoic time. Geology 10, 516-519. https://doi.org/10.1130/0091-7613(1982)10<516:VOSSTP > 2.0.CO;2.
Bustillo, M.Á., Plet, C., Alonso-Zarza, A.M., 2013. Root calcretes and uranium-bearing silcretes at sedimentary discontinuities in the miocene of the Madrid Basin (Toledo, Spain). J. Sediment. Res. 83 (12), 1130-1146. https://doi.org/10.2110/jsr.2013.85.

Calvet, F., Pomar, L., Esteban, M., 1975. Las rizocreciones del Pleistoceno de Mallorca: Revista del Instituto de Investigaciones Geológicas. 30. Universidad de Barcelona, pp. 35-60.

Candy, I., Adamson, K., Gallant, C.E., Whitfield, E., Pope, R., 2012. Oxygen and carbon isotopic composition of Quaternary meteoric carbonates from western and southern Europe: their role in palaoenvironmental reconstruction. Palaeogeogr.

Palaeoclimatol. Palaeoecol. 326-328, 1-11. https://doi.org/10.1016/j.palaeo.2011. 12.017.

Capo, R.C., Stewart, B.W., Chadwick, O.A., 1998. Strontium isotopes as tracers of ecosystem processes: Theory and methods. Geoderma 82 (1-3), 197-225. https://doi. org/10.1016/S0016-7061(97)00102-X.

Capo, C., Whipkey, C.E., Blachère, J.R., Chadwick, O.A., 2000. Pedogenic of dolomite in a basaltic weathering profile, Kohala peninsula, Hawaii. Geology 28, 271-274. https:// doi.org/10.1130/0091-7613(2000)28<271:POODIA > 2.0.CO;2.

Carracedo, J.C., Pérez Torrado, F.J., Rodríguez Badiola, E., 2008. Canarias: Islas volcánicas intraplaca. In: Pérez Torrado, F.J., Cabrera, M.E. (Eds.), Itinerarios geológicos por las Islas Canarias. Gran Canaria. Sociedad Geológica de España, Las Palmas de Gran Canaria, pp. 11-25.

Casado, A.I., Alonso-Zarza, A.M., La Iglesia, A., 2014. Morphology and origin of dolomite in paleosols and lacustrine sequences. Examples from the Miocene of the Madrid Basin. Sediment. Geol. 312, 50-62. https://doi.org/10.1016/j.sedgeo.2014.07.005.

Casado, A.I., Alonso-Zarza, A.M., Martín-Pérez, A., 2018. Caracterización y origen de las estructuras prismáticas de paleosuelos dolomíticos. Paracuellos de Jarama, Mioceno, Cuenca de Madrid. Geogaceta 63, 111-114.

Casamayor, M., Alonso, I., Sánchez-García, M.J., Montoya-Montes, I., Rodríguez, S., Mangas, J., 2019. Análisis sedimentológico de la costa meridional de Telde (Gran Canaria, España). In: Durán, R., Guillén, J., Simarro, G. (Eds.), X Jornadas de Geomorfología Litoral. Castelldefels, Barcelona, Spain, pp. 49-52.

Colson, J., Cojan, I., 1996. Groundwater dolocretes in a lake-marginal environments: an alternative model for dolocrete formation in continental settings (Danian of the Provence Basin, France). Sedimentology 43, 175-188. https://doi.org/10.1111/j. 1365-3091.1996.tb01466.x.

Cousens, B.L., Spera, F.J., Tilton, G.R., 1990. Isotopic patterns in silicic ignimbrites and lava flows of the Mogan and lower Fataga Formations, Gran Canaria, Canary Islands: temporal changes in mantle source composition. Earth Planet. Sci. Lett. 96 (3-4), 319-335. https://doi.org/10.1016/0012-821X(90)90010-U.

Criado, C., 1988. Evolución Geomorfológica de Fuerteventura. Universidad de La Laguna, $\mathrm{PhD}$.

Criado, C., Torres, J.M., Hansen, A., Lillo, P., Naranjo, A., 2011. Intercalaciones de polvo sahariano en paleodunas bioclásticas de Fuerteventura (Islas Canarias). Cuaternario y Geomorfología 26, 73-88.

Cuadros, J., Diaz-Hernandez, J.L., Sanchez-Navas, A., Garcia-Casco, A., Yepes, J., 2016. Chemical and textural controls on the formation of sepiolite, palygorskite and dolomite in volcanic soils. Geoderma 271, 99-114. https://doi.org/10.1016/j. geoderma.2016.01.042.

Danmati, B., 1997. Mineralogical and sedimentological characterization of Quaternary eolian formations and paleosols in Fuerteventura and Lanzarote (Canary Island, Spain). In: Petit-Maire, N. (Ed.), Meco, J. Climates of the Past. Servicio de Publicaciones Universidad de Las Palmas de Gran Canaria, Las Palmas de Gran Canaria, pp. 71-78.

Díaz-Hernández, J.L., Sánchez-Navas, A., Reyes, E., 2013. Isotopic evidence for dolomite formation in soils. Chem. Geol. 347, 20-33. https://doi.org/10.1016/j.chemgeo. 2013.03.018.

Diaz-Hernandez, J.L., Sánchez-Navas, A., Delgado, A., Yepes, J., Garcia-Casco, A., 2018. Textural and isotopic evidence for Ca-Mg carbonate pedogenesis. Geochim. Cosmochim. Ac. 222, 485-507. https://doi.org/10.1016/j.gca.2017.11.006.

Eren, M., Kaplan, M.Y., Kadir, S., Kapur, S., 2018. Biogenic ( $\beta$-fabric) features in the hard laminated crusts of the Mersin and Adana regions, southern Turkey and the role of soil organisms in the formation of the calcrete profiles. Catena 168, 34-46. https:// doi.org/10.1016/j.catena.2017.12.021.

Esteban, M., Klappa, C., 1983. Subaerial exposure environment. In: Scholle, P.A., Debout, D.G., Moore, C.H. (Eds.), Carbonate Depositional Environments, Memoir 33. The American Association of Petroleum Geologists, Oklahoma, USA, pp. 1-54.

Fedoroff, N., Country, M.A., Lacroix, E., Oleschko, K., 1994. Calcitic accretion on in durated volcanic materials (example of tepetates, Altiplano, Mexico). In: Proceedings XVth World Congress, Soil Science, Acapulco 6A, pp. 459-472.

Genise, J.F., Alonso-Zarza, A.M., Verde, M., Meléndez, A., 2013. Insect trace fossils in aeolian deposits and calcretes from the Canary Islands: their ichnotaxonomy, producers, and palaeoenvironmental significance. Palaeogeogr. Palaeoclimatol. Palaeoecol. 377, 110-124. https://doi.org/10.1016/j.palaeo.2013.03.005.

Gile, L.H., Peterson, F.F., Grossman, R.B., 1966. Morphological and genetic sequences of carbonate accumulation in desert soils. Soil Sci. 101, 347-360. https://ui.adsabs. harvard.edu/link_gateway/1966SoilS.101..347G/doi:10.1097/00010694196605000-00001.

Goudie, A.S., 1973. Duricrusts in Tropical and Subtropical Landscapes. Claredon, Oxford (174 pp).

Goudie, A.S., Middleton, N.J., 2001. Saharan dust storms: nature and consequences. Earth-Sci. Rev. 56, 179-204. https://doi.org/10.1016/S0012-8252(01)00067-8.

Hamidi, E.M., Colin, F., Michard, A., Boulange, B., Nahon, D., 2001. Isotopic tracers of the origin of $\mathrm{Ca}$ in a carbonate crust from the Middle Atlas, Morocco. Chem. Geol. 176, 93-104. https://doi.org/10.1016/S0009-2541(00)00373-9.

Hansteen, T.H., Troll, V.R., 2003. Oxygen isotope composition of xenoliths from the oceanic crust and volcanic edifice beneath Gran Canaria (Canary Islands): 
consequences for crustal contamination of ascending magmas. Chem. Geol. 193 (3-4), 181-193. https://doi.org/10.1016/S0009-2541(02)00325-X.

Hay, R.L., Reeder, R.J., 1978. Calcretes of Olduvai Gorge and the Ndolanya beds of northern Tanzania. Sedimentology 25 (5), 649-673. https://doi.org/10.1111/j.13653091.1978.tb00324.x.

Hay, R.L., Wiggins, B., 1980. Pellets, ooids, sepiolite and silica in three calcretes of the southewestern United States. Sedimentology 27, 559-576. https://doi.org/10.1002/ 9781444304497.ch2.

Hollik, J.S., Rabinowitz, P.D., Austin, J.A., 1991. Effects of Canary hotspot volcanism on the structure of oceanic crust off Morocco. J. Geophys. Res. 96 (B7), 12039-12067. https://doi.org/10.1029/91JB00709.

Huerta, P., Rodríguez-Berriguete, A., Martín-García, R., Martín-Pérez, A., La, Iglesia, Alonso-Zarza, A., 2015. The role of climate and eolian dust input in calcrete formation in volcanic islands (Lanzarote and Fuerteventura, Spain). Palaeogeogr. Palaeoclimatol. Palaeoecol. 417, 66-79. https://doi.org/10.1016/j.palaeo.2014.10. 008.

Jaén, M.V.M., Suárez, P.M., 2012. Algunas reflexiones acerca del clima de las Islas Canarias. In: Nimbus: Revista de climatología, meteorología y paisaje. 29-30. pp. 399-416.

Jones, B., 1992. Construction of spar calcite crystals around spores. J. Sediment. Petrol. 62, 1054-1057. https://doi.org/10.1306/D4267A46-2B26-11D78648000102C1865D.

Jutras, P., 2017. Climate fluctuations recorded in phreatic and vadose calcretes of the Lower Carboniferous Clyde Sandstone Formation of Machrihanish, Kintyre Peninsula, SW Scotland. J. Geol. Soc. London 174 (4), 646-654. https://doi.org/10.1144/ jgs2016-043.

Jutras, P., Young, G.M., Caldwell, W.G.E., 2011. Reinterpretation of James Hutton's historic discovery on the Isle of Arran as a double unconformity masked by a phreatic calcrete hardpan. Geology 39 (2), 147-150. https://doi.org/10.1130/G31490.1.

Khadkikar, A.S., Chamyal, L.S., Ramesh, R., 2000. The character and genesis of calcrete in late Quaternary alluvial deposits, Gujarat, western India, and its bearing on the interpretation of ancient climates. Palaeogeogr. Palaeoclimatol. Palaeoecol. 162, 239-261. https://doi.org/10.1016/S0031-0182(00)00130-9.

Klappa, C.F., 1980. Brecciation textures and tepee structures in Quaternary calcrete (caliche) profiles from eastern Spain: the plant factor in their formation. Geol. J. 15 (2), 81-89. https://doi.org/10.1002/gj.3350150202.

Kraus, M.J., 1999. Paleosols in clastic sedimentary rocks: their geologic applications. Earth-Sci. Rev. 47, 41-70. https://doi.org/10.1016/S0012-8252(99)00026-4.

Kuznetsov, A.B., Semikhatov, M.A., Gorokhov, I.M., 2012. The Sr isotope composition of the world ocean, marginal and inland seas: Implications for the $\mathrm{Sr}$ isotope stratigraphy. Stratigr. Geol. Correl. 20 (6), 501-515. https://doi.org/10.1134/ S0869593812060044.

Machette, M.N., 1985. Calcic soils of southwestern United States. In: Weide, D.L. (Ed.), Soil and Quaternary Geology of the Southwestern United States. Geological Society of America Special Paper 203. pp. 1-21.

Mack, G.H., James, W.C., 1993. Control on basin symmetry on fluvial lithofacies, Camp Rice and Palomas Formation (Plio-Pleistocene), southern Rio Grande rift, USA. In Marzo, M., Puigdefábregas, C. (Eds.), Alluvial sedimentation. The International Association of Sedimentologists, Blackwell Scientific Publications, Oxford, pp. 439-449. https://doi.org/10.1002/9781444303995.ch28.

Mangas, J., Alonso, I., Betancor, J.F., Casamayor, M., Juliá, M., Menéndez, I., Montoya, I., Quevedo, L.A., Rodríguez, S., Sánchez, M.J., Yepes, J., 2018. Sistemas playa duna actuales y fósiles en la costa sur de Telde (Este de Gran Canaria): Registro de cambios globales del nivel de mar en tiempos geológicos recientes. Technical report founded by City Hall of Telde and FDCAN, Mangas, J. (Ed.), (Las Palmas de Gran Canaria, 275 pp).

Marriott, S.B., Wright, V.P., 1993. Palaeosols as indicator of geomorphic stability in two Old Red Sandstone alluvial suites, South Wales. J. Geol. Soc. London 150, 1109-1120. https://doi.org/10.1144/gsigs.150.6.1109.

Martín-Pérez, A., Alonso-Zarza, A.M., Iglesia, A.L., Martín-García, R., 2015. Do magnesian clays play a role in dolomite formation in alkaline environments? An example from Castañar Cave, Cáceres (Spain). Geogaceta 57, 15-18.

Mather, C.C., Nash, D.J., Skrzypek, G., Dogramaci, S., Grierson, P.F., 2019. Geomorphic and hydrological controls on groundwater dolocrete formation in the semi-arid Hamersley Basin, northwest Australia. Earth Surf. Process. Landforms 44, 2752-2770. https://doi.org/10.1002/esp.4704.

Mazzullo, S.J., Birdwell, B.A., 1989. Syngenetic formation of grainstones and pisolites from fenestral carbonates in peritidal settings. J. Sediment. Res. 59 (4), 605-611. https://doi.org/10.1306/212F9002-2B24-11D7-8648000102C1865D.

McCrea, J.M., 1950. On the isotope chemistry of carbonates and paleotemperature scale. J. Chem. Phys. 18, 849-857. https://doi.org/10.1063/1.1747785.

Meco, J., 2008. Historia Geológica del clima en Canarias. International Union of Geological Sciences. Unesco and ULPGC, Las Palmas de Gran Canaria (296 pp).

Meléndez, A., Alonso-Zarza, A.M., Sancho, C., 2011. Multi-storey calcrete profiles developed during the initial stages of the configuration of the Ebro Basin's exorrheic fluvial network. Geomorphology 134 (3), 232-248. https://doi.org/10.1016/j. geomorph.2011.06.032.

Menéndez, I., Derbyshire, E., Engelbrecht, J., von Suchodoletz, H., Zoller, L., Dorta, P., Carillo, T., Rodriguez de Castro, F., 2009b. Saharan dust and the aerosols on the Canary Islands: Past and present. In: Cheng, M., Liu, W. (Eds.), Airborne Particulates. Novapublishers, Hauppauge, NY, pp. 39-80

Menéndez, I., Díaz-Hernández, J.L., Mangas, J., Alonso, I., Sánchez-Soto, P.J., 2007. Airborne dust accumulation and soil development in the North-East sector of Gran Canaria (Canary Islands, Spain). J. Arid Environ. 71 (1), 57-81. https://doi.org/10 1016/j.jaridenv.2007.03.011.

Menéndez, I., Cabrera, L., Sánchez-Pérez, I., Mangas, J., Alonso, I., 2009a.
Characterisation of two fluvio-lacustrine loessoid deposits on the island of Gran Canaria, the Canary Islands. Quatern. Int. 196, 36-43. https://doi.org/10.1016/j. quaint.2008.05.011.

Menéndez, I., Mangas, J., Tauler, E., Barrón, V., Torrent, J., Betancort, J.F., Santana, A., Recio, J.M., Quevedo-González, L.A., Alonso, I., Méndez, J., 2019. Aeolian influx and related environmental conditions on Gran Canaria during the early Pleistocene ERRATUM. Quaternary Res. 91 (1), 452. https://doi.org/10.1017/qua.2019.3. (Aeolian influx and related environmental conditions on Gran Canaria during the early Pleistocene. Quaternary Res. 91 (1), 35-50. doi.10.1017/qua.2018.64).

Mestre, A., Felipe, L., 2012. Atlas Climático de los Archipiélagos de Canarias, Madeira y Azores: Temperatura del Aire y Precipitación (1971-2000). Agencia estatal de Meteorología e Instituto de Meteorología de Portugal, Lisboa.

Miller, C.R., James, N.P., 2012. Autogenic microbial genesis of middle Miocene palustrine ooids; Nullarbor Plain, Australia. J. Sediment. Res. 82 (9), 633-647. https://doi.org/ 10.2110/jsr.2012.60.

Muhs, D.R., Budahn, J., Skipp, G., Prospero, J.M., Patterson, D., Bettis Iii, E.A., 2010. Geochemical and mineralogical evidence for Sahara and Sahel dust additions to Quaternary soils on Lanzarote, eastern Canary Islands, Spain. Terra Nova 22 (6), 399-410. https://doi.org/10.1111/j.1365-3121.2010.00949.x.

O'Neil, J.R., Epstein, S., 1966. Oxygen isotope fractionation in the system dolomite-calcite-carbon dioxide. Science 152 (3719), 198-201. https://doi.org/10.1126/science. 152.3719.198.

Ovchinnikova, G.V., Belyatskii, B.V., Vasil'eva, I.M., Levskii, L.K., Grachev, A.F., Arana, V., Mithavila, J., 1995. Sr-Nd-Pb isotope characteristics of the mantle sources of basalts from the Canary Islands. Petrology 3 (2), 172-182. https://doi.org/10.1016/ S0377-0273(00)00228-6.

Pérez-Torrado, F.J., Martí, J., Queralt, I., Mangas, J., 1995. Alteration processes of the Roque Nublo ignimbrites (Gran Canaria, Canary Islands). J. Volcanol. Geoth. Res. 65, 191-204. https://doi.org/10.1016/0377-0273(94)00115-W.

Price, W.A., 1925. Caliche and pseudo-anticlines. AAPG Bull. 9 (6), 1009-1017.

Prokoph, A., Shields, G.A., Veizer, J., 2008. Compilation and time-series analysis of a marine carbonate $\delta^{18} \mathrm{O}, \delta^{13} \mathrm{C},{ }^{87} \mathrm{Sr} /{ }^{86} \mathrm{Sr}$ and $\delta^{34} \mathrm{~S}$ database through Earth history. Earth-Sci. Rev. 87 (3-4), 113-133. https://doi.org/10.1016/j.earscirev.2007.12.003.

Prospero, J.M., 1996. Dust transport over the North Atlantic Ocean and Mediterranean: an overview. In: Guerzoni, S., Chester, R. (Eds.), The Impact of Desert Dust across the Mediterranean. Kluwer Academic Publishing, Dordrecht, pp. 133-151.

Prospero, J.M., Lamb, P.J., 2003. African droughts and dust transport to the Caribbean: climate change implications. Science 302, 1024-1027. https://doi.org/10.1126/ science. 1089915

Pye, K., 1987. Aeolian Dust and Dust Deposits. Academic Press, London (334 pp).

Quade, J., Cerling, T.E., Bowman, J.R., 1989. Systematic variations in the carbon and oxygen isotopic composition of pedogenic carbonate along elevation transects in the southern Great Basin, United States. Geol. Soc. Am. Bull. 101, 464-475. https://doi. org/10.1130/0016-7606(1989)101\%3C0464:SVITCA\%3E2.3.CO;2.

Rodríguez-Berriguete, Á., Alonso-Zarza, A.M., 2019. Controlling factors and implications for travertine and tufa deposition in a volcanic setting. Sediment. Geol. 381, 13-28. https://doi.org/10.1016/j.sedgeo.2018.12.001.

Scheuvens, D., Schütz, L., Kandler, K., Ebert, M., Weinbruch, S., 2013. Bulk composition of northern African dust and its source sediments-a compilation. Earth-Sci. Rev. 116, 170-194. https://doi.org/10.1016/j.earscirev.2012.08.005.

Schmincke, H.-U., Klügel, A., Hansteen, T.H., Hoernle, K., van den Bogaard, P., 1998 Samples from the Jurassic ocean crust beneath Gran Canaria, La Palma and Lanzarote (Canary Islands). Earth Planet. Sci. Lett. 163, 343-360. https://doi.org/10.1016/ S0012-821X(98)00168-X.

Singh, B.P., Lee, Y.I., 2007. Atmospheric $\mathrm{pCO}_{2}$ and climate during late Eocene (36 \pm 5 $\mathrm{Ma}$ ) on the Indian subcontinent. Curr. Sci. India 92, 518-523.

Steiner, C., Hobson, A., Favre, P., Stampfli, G.M., Hernandez, J., 1998. Mesozoic sequence of Fuerteventura (Canary Islands): witness of early Jurassic Sea-floor spreading in the Central Atlantic. Geol. Soc. Am. Bull. 110, 1304-1317. https://doi.org/10.1130/ 0016-7606(1998)110\%3C1304:MSOFCI\%3E2.3.CO;2.

von Suchodoletz, H., Kühn, P., Hambach, U., Dietz, M., Zöller, L., Faust, D., 2009. Loesslike and palaeosol sediments from Lanzarote (Canary Islands / Spain) - indicators of palaeoenvironmental change during the late Quaternary. Palaeogeogr. Palaeoclimatol. Palaeoecol. 278, 71-87. https://doi.org/10.1016/j.palaeo.2009.03. 019.

von Suchodoletz, H., Oberhänsli, H., Hambach, U., Zöller, L., Fuchs, M., Faust, D., 2010 Soil moisture fluctuations recorded in Saharan dust deposits on Lanzarote (Canary Islands) over the last 180ka. Quat. Sci. Rev. 29, 2173-2184. https://doi.org/10. 1016/j.quascirev. 2010.05.014.

Tanner, L.H., 2010. Continental Carbonates as Indicators of Paleoclimate. In: AlonsoZarza, A.M., Tanner, L.H. (Eds.), Carbonates in Continental Settings: Geochemistry, Diagenesis and Applications. Developments in sedimentology. 62. Elsevier, Amsterdam, pp. 179-214. https://doi.org/10.1016/S0070-4571(09)06204-9.

Thirlwall, M.F., Jenkins, C., Vroon, P.Z., Mattey, D.P., 1997. Crustal interaction during construction of ocean islands: $\mathrm{Pb}-\mathrm{Sr}-\mathrm{Nd}-\mathrm{O}$ isotope geochemistry of the shield basalts of Gran Canaria, Canary Islands. Chem. Geol. 135 (3), 233-262. https://doi.org/10. 1016/S0009-2541(96)00118-0.

Watts, N.L., 1977. Pseudo-anticlines and other structures in some calcretes of Botswana and South Africa. Earth Surf. Process. 2 (1), 63-74. https://doi.org/10.1002/esp. 3290020107.

Whipkey, C.E., Capo, R.C., Hsieh, J.C.C., Chadwick, O.A., 2002. Development of Magnesian Carbonates in Quaternary Soils on the Island of Hawaii. J. Sediment. Res. 72, 158-165. https://doi.org/10.1306/050801720158.

Whipkey, Ch.E., Hayob, J.L., 2008. Textural and compositional evidence for the evolution of pedogenic calcite and dolomite in a weathering profile on the Kohala Peninsula. Hawaii. Carbonate. Evaporite. 23, 104-112. https://doi.org/10.1007/BF03176156. 
Williams, C.A., Krause, F.F., 1998. Pedogenic-phreatic carbonates on a Middle Devonian (Givetian) terrigenous alluvial-deltaic plain, Gilwood Member (Watt Mountain Formation), northcentral Alberta, Canada. Sedimentology 45, 1105-1124. https:// doi.org/10.1046/j.1365-3091.1998.00192.x.

Wright, V.P., 2007. Calcrete. In: Nash, D.J., McLaren, S.J. (Eds.), Geochemical Sediments and Landscapes. Blackwell, Oxford, pp. 10-41.

Wright, V.P., Alonso-Zarza, A.M., 1990. Pedostratigraphic models for alluvial fan deposits: a tool for interpreting ancient sequences. J. Geol. Soc. Lond. 147, 8-10. https://doi.org/10.1144/gsigs.147.1.0008.

Wright, V.P., Marriott, S.B., 1996. A quantitative approach to soil occurrence in alluvial deposits and its application to the Old Red Sandstone of Britain. J. Geol. Soc. Lond. 153, 907-913. https://doi.org/10.1144/gsjgs.153.6.0907.

Wright, V.P., Tucker, M.E., 1991. Calcretes: An introduction. In: Wright, V.P., Tucker, M.E. (Eds.), Calcretes. IAS Reprint series 2. Blackwell Scientific Publications, Oxford, pp. 1-22.

Wright, V.P., Platt, N.H., Wimbledon, W.A., 1988. Biogenic laminar calcrete: evidences of calcified root-mat horizons in paleosols. Sedimentology 35, 603-620. https://doi. org/10.1002/9781444304497.ch13.

Wright, V.P., Platt, N.H., Marriott, S.B., Beck, V.H., 1995. A classification of rhizogenic (root-formed) calcretes, with examples from the Upper Jurassic-Lower Cretaceous of Spain and Upper Cretaceous of southern France. Sediment. Geol. 100, 143-158. https://doi.org/10.1016/0037-0738(95)00105-0.

Yanes, Y., Delgado, A., Castillo, C., Alonso, M.R., Ibáñez, M., De la Nuez, J., Kowalewski, M., 2008. Stable isotope $\left(\delta^{18} \mathrm{O}, \delta^{13} \mathrm{C}\right.$, and $\left.\delta \mathrm{D}\right)$ signatures of recent terrestrial communities from a low-latitude, oceanic setting: endemic land snails, plants, rain, and carbonate sediments from the eastern Canary Islands. Chem. Geol. 249, 377-392. https://doi.org/10.1016/j.chemgeo.2008.01.008. 